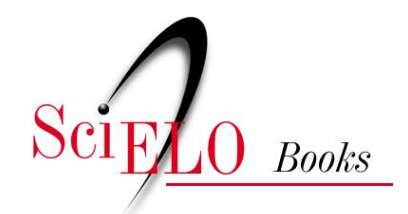

\title{
O Esteta e o "Cínico"
}

\author{
Jorge Alberto Rocha
}

\section{SciELO Books / SciELO Livros / SciELO Libros}

ROCHA, JAC. O Esteta e o "Cínico". In: Michel Foucault: crítico-esteta-cínico mitigado [online]. Campina Grande: EDUEPB. Substractum collection, 2014, pp. 211-286. ISBN 978-85-7879-184-1. Available from SciELO Books $<\underline{\text { http://books.scielo.org }>\text {. }}$

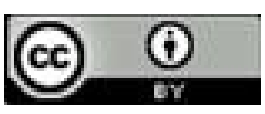

All the contents of this work, except where otherwise noted, is licensed under a Creative Commons Attribution $\underline{4.0 \text { International license. }}$

Todo o conteúdo deste trabalho, exceto quando houver ressalva, é publicado sob a licença Creative Commons Atribição 4.0.

Todo el contenido de esta obra, excepto donde se indique lo contrario, está bajo licencia de la licencia $\underline{\text { Creative }}$ Commons Reconocimento 4.0. 


\section{O Esteta e o "Cínico"}

\section{Os perigos da razão e a ética}

Michel Foucault reterritorializa a crítica kantiana, e a sua conclusão, a partir do empreendimento crítico realizado por este autor é a seguinte:

[...] se há de colocar a questão do conhecimento em sua relação com a dominação seria, em princípio e antes de qualquer coisa, essa vontade decidida que é atitude, ao mesmo tempo individual e coletiva, de sair - como dizia Kant - de seu próprio e culpável estado de tutela. É um assunto de atitude (FOUCAULT, 1995, p. 18, grifo nosso).

Pensa-se que esse caráter de "atitude" em Foucault deva ser levado a sério. E este nos reenvia diretamente, ou até melhor, este nasce perfazendo uma ponte entre o horizonte da crítica e o horizonte da ética, um novo "território" a ser incorporado àquele, do mesmo modo sugerindo um retorno relativamente à questão da modernidade em Foucault. Ora, uma 
vez que o próprio Kant caiu em paradoxos e em ambiguidades, como visto no Capítulo II; uma vez que a saída que ele propõe da menoridade ficou envolta em inúmeras dificuldades, o que mais assimilar do seu projeto? Para além, ou melhor, no âmbito da tarefa do diagnóstico, se o projeto da modernidade em Michel Foucault é visto mais como uma "atitude" do que como um período histórico, é segundo três aspectos: "um modo de relação com respeito à atualidade; uma escolha voluntária que é feita por alguns; enfim, uma maneira de pensar e de sentir, uma maneira também de agir e de se conduzir" (FOUCAULT, “What is Enlightenment? ('Qu'est-ce que les Lumières')", DE, IV, 1994, p. 568). Um pouco o ethos, em sentido grego, e que encontra um bom exemplo na perspectiva de Baudelaire.

Como é lembrado por Katya Muricy (In: CASTELO BRANCO; PORTOCARRERO, 2000, p. 296), Baudelaire foi, surpreendentemente, uma "quase ausência" nos estudos foucaultianos, pois, embora o compreendendo como "uma das consciências mais agudas da modernidade" (FOUCAULT, “Qu'est-ce-que les Lumières?”, DE, IV, 1994, p. 568), Baudelaire só aparece decisivamente nos anos 80. Por ele foi importante? Para este, ser moderno significa prender-se ao presente como algo de transitório ou contingente, rompendo com a tradição, mas, ao mesmo tempo, assumindo uma atitude frente a este presente. Consiste em levar consigo uma vontade de heroificar o presente, conquanto que esta seja irônica, ou seja, não só abrir os olhos para o que se passa, atitude de passeante [flânerie], mas ser exercício onde o "real é confrontado à prática de uma liberdade que a todo momento respeita o real e o viola" (FOUCAULT, "What is Enlightenment? ('Qu'est-ce que les Lumières')", DE, IV, 1994, p. 570-571, grifo nosso). Por fim, além de ser relação 
para com o presente, significa também relação consigo mesmo. $\mathrm{O}$ "'dandysme" baudelaireiano pensa o homem moderno como aquele que procura inventar-se a si mesmo, antes de procurar alguma verdade do homem escondida não se sabe onde. Porém, é o quarto momento, não possível através da sociedade ou política; só possível pelo terreno da arte.

Muricy completa a posição de Baudelaire na perspectiva foucaultiana da seguinte forma:

Se o poeta a define [a modernidade] como 'o transitório, o fugidio, o contingente', a atitude da modernidade que Foucault encontra em Baudelaire é aquela que o leva a não simplesmente constatar e se contentar com esta apreensão da descontinuidade do tempo, mas, ao contrário, a que exige uma tomada de posição que, de certo modo, se opõe à transitoriedade (MURICY, in: CASTELO BRANCO; PORTOCARREO, 2000, p. 305).

É preciso operar a "reativação permanente de uma atitude", e isso é traduzido como uma "crítica permanente de nosso ser histórico" (FOUCAULT, “What is Enlightenment? ('Qu'est-ce que les Lumières')”, DE, IV, 1994, p. 571), com conotações negativas e positivas. "Negativamente", não ficar preso à dicotomia contra ou a favor da Aufklärung, alternativa simples, fácil, autoritária, levando ora a aceitar os pressupostos do seu racionalismo, ora a rechaçá-lo por completo; ao invés disso, pensa Foucault, precisa-se revitalizar a questão de uma autonomia do sujeito no interior de pesquisas históricas precisas, sem voltar-se para algo como o "núcleo essencial de 
racionalidade" do "Esclarecimento", embora constatando o quanto fomos "determinados" por essa racionalidade. A partir daí poder-se-ia identificar aquilo que é ou não indispensável para a "constituição de nós mesmos como sujeitos autônomos" (FOUCAULT, "What is Enlightenment? ('Qu' est-ce que les Lumières')", DE, IV, 1994, p. 572). A segunda crítica negativa consiste em se fugir da relação confusa e por demais fácil também entre Aufklärung e humanismo, mas disso já foi abordado nesta tese.

O caminho, então, ao invés de se concentrar nessa possível relação Aufklärung/humanismo, fruto de uma "confusão" histórica e moral, deve ensejar a realização de uma "crítica" e "criação permanente de nós mesmos em nossa autonomia", princípio que estava no "coração da Aufklärung", e que não exigia nenhuma necessidade de um aporte ou identificação a algum humanismo. Ao contrário, mostrava uma "tensão" entre ambos (FOUCAULT, "What is Enlightenment? ('Qu'est-ce que les Lumières')”, DE, IV, 1994, p. 573, grifo nosso).

Mas há o lado "positivo" a se verificar. Foucault os enumera em dois: o primeiro consiste em entender o êthos filosófico como "atitude limite". Ou seja, se o problema em Kant era identificar os limites do conhecimento humano, a "crítica" hodierna tentaria destacar, daquilo que é "universal, necessário, obrigatório, qual é a parte daquilo que é singular, contingente e fruto de coações arbitrárias" (FOUCAULT, "What is Enlightenment? ('Qu'est-ce que les Lumières')", DE, IV, 1994, p. 574). O deslocamento feito por Foucault visa a recuar a análise diante de um componente transcendental (a "condição de possibilidade" em Kant), avançando em uma pesquisa arqueológica e genealógica: a primeira, na medida em que os pensamentos, ditos e atos fossem observados e 
retirados de onde eles brotavam, dos "acontecimentos históricos" (a ênfase, pois, não recai na atividade filosófica de gabinete); a segunda, importante por mostrar o que se é a partir de sua contingência (FOUCAULT, "What is Enlightenment? ('Qu'est-ce que les Lumières')”, DE, IV, 1994, p. 574). Daí que essa pesquisa em dupla mão não buscará "tornar possível a metafísica enfim tornada ciência; ela busca relançar tão longe e tão amplo quanto possível o trabalho indefinido da liberdade" (FOUCAULT, "What is Enlightenment? ('Qu'est-ce que les Lumières')”, DE, IV, 1994, p. 574).

O segundo lado positivo, contra o sonho vazio de liberdade, através de uma metafísica tornada ciência, vai na direção de uma atitude "histórico-crítica" como "atitude experimental". Quer dizer, tanto se dirigir a pesquisas históricas, quanto a uma volta para a realidade e atualidade. $\mathrm{O}$ que queremos mudar? E como fazê-lo? São as perguntas a serem feitas, entendendo que tais mudanças em Foucault não devem ser nem radicais nem globais, mas locais e precisas. Elas ganham em preferência e eficácia, ao invés daquelas "promessas do homem novo que os piores sistemas políticos repetiram ao longo do século XX" (FOUCAULT, "What is Enlightenment? ('Qu'est-ce que les Lumières')”, DE, IV, 1994, p. 573). Assim, pensa Foucault, quais as transformações detectáveis hoje nos "modos de ser e de pensar", nas "relações de autoridade", nas "relações sexuais", na "maneira pela qual percebemos a loucura ou a doença" (FOUCAULT, "What is Enlightenment? ('Qu'est-ce que les Lumières')”, DE, IV, 1994, p. 575)?

Aportando no horizonte da genealogia da moral, colocando isso no "primeiro plano", usando as palavras de Kraemer (2011, p. 275), sobressaem-se os volumes II e III da sua histoire de la sexualité (L'usage des plaisirs (2002c) e Le souci de soi 
(2003d) e boa parte daquilo que ele produziu nos ano 80, seja nas entrevistas, artigos etc. contidos em Dits et écrits, seja nos seus cursos no Collège de france. Ora, a partir da herança crítica kantiana, fica a questão de como unir moral e racionalidade. Quer dizer, a resposta foucaultiana ao "O que devo fazer?" de Kant, uma vez que já se vislumbrou a sua resposta crítica em torno de "O que posso saber?", "o que posso esperar?" e "o que é o homem?", as perguntas fundamentais de Kant.

Ora, a solução kantiana para o problema da moral vai se concentrar não propriamente na ação, mas na vontade. No quadro da "antropologia" kantiana, como essa vontade, no sujeito, nem sempre é subordinada aos ditames da razão, a tarefa do filósofo foi redirecioná-lo para tal instância. Assim, determinada a vontade pela razão pode surgir o "imperativo", a regra "designada por um dever" (KANT, 1986, p. 30). Nesse sentido, a vontade em Kant não representaria um simples desejo de alguém, mas algo "sob recurso a todos os meios, na medida em que estejam sob meu poder'" (TUGENDHAT, 1996, p. 109). Ou seja, o dever, como "bem", não deve nascer de inclinações subjetivas e imediatas - faculdade apetitiva sensitiva - senão de uma "faculdade apetitiva superior", “determinada pela razão" (TUGENDHAT, 1996, p. 113).

Mas, colocando o "afeto no lugar do dever" não se divide o homem, ou a natureza humana, em duas partes? Para Hegel e Schiller, segundo Tugendhat, tal seria o problema filosófico então instaurado, sem falar no seu problema moral, uma vez "que não é mais o homem como um todo que age moralmente" (TUGENDHAT, 1996, p.117). A vontade, por seu turno, precisa ser vontade livre. Uma ação forçada, por exemplo, não pode fazer de nós responsáveis moralmente por ela. O que 
quer dizer que nunca se julga a ação mesma, senão a vontade do sujeito que, livre, pôs-se a agir. Segundo Tugendhat (1996, p. 105) este ponto permaneceria irrepreensível no âmbito do saber ético; ou seja, como o resume Kant, logo no Prefácio da sua Crítica da razão pura (1985, p. 12), “a liberdade [...] é a condição da lei moral". O que não eximiria Kant de algumas críticas, uma vez que o imperativo kantiano surge como um preceito de razão cuja ausência de determinações objetivas, isto é, dispondo apenas de "um conjunto de exigências mínimas, desprovidas de substância real" (BORGES et. al., 2002, p. 27) decorria necessariamente dos seus pressupostos. Afinal, um conteúdo a ser dado para a moral esbarraria nos limites do nosso conhecimento.

Quanto a Foucault, a pergunta "O que devo fazer?" parte de um princípio de base totalmente diferente. Se com Kant a questão é buscar uma regra que possa ser, ao mesmo tempo, "objetiva e universalmente válida", expurgadas as "condições contingentes e subjetivas" (KANT, 1986, p. 31), a meta foucaultiana foi a de proceder a uma desconfiança mesma na razão, entendendo isso nem como uma defesa e nem como uma recusa recusa incondicionais desta, mas a tomando "“como um problema histórico"' (KRAEMER, 2011, p. 286). Nesse sentido parece que Foucault inverte de alguma maneira aquele poder, e foi o que se viu em muitos momentos, os quais são sintetizados agora:

1. Não há um progresso da razão, há um uso dela feito pela cultura (tomado em sentido amplo) que, nos seus mais variados meios formais, serve para limitar as pessoas. Assim, invertendo os termos, a razão não deve ser o juiz de si mesma, na busca 
pelos seus limites; é aquilo que a razão mesma, manifestando-se, busca limitar desse sujeito o que deve ser atentado;

2. Os governos não podem se curvar aos ditames da razão; invertendo as coisas novamente, é esta que busca, ao invés, legitimá-los, e seu poder sobre a população (biopoder), pautado sob a égide geral da norma, é que rege os processos ditos "racionais";

3. O uso feito da razão pela cultura ocidental serviu, em muitos casos, para engendrar processo de exclusão: do louco, como o desrazoável; do doente, como alguém cujo cuidado do corpo próprio deve se submeter à tutela do médico; do delinqüente que, como tal, é alguém desrazoável, devendo ser enquadrado dentro das normas sociais aceitas e, para isso, submetido a toda uma prática médico-psiquiátrica normalizadora;

4. Mas até alguns mínimos gestos podem sofrer efeitos normalizantes, como o que se viu acerca dos homens infames;

5. O humanismo também não é visto por Michel Foucault como uma iniciativa de pensamentos sãos voltados para os valores humanos, mas para processos vários de soberania: sobre o corpo, sobre uma verdade canônica, referendada, por exemplo, pela ciência, e sempre tendo em vista regras sociais;

6. Sobre esse ponto, se a razão busca uma verdade, seja naquilo que ela constata como "o que é", seja naquilo que se deve fazer em seguida, é esta mesma vedade 
que deve ser interrogada em seus efeitos de poder. Feita tal interrogação, a razão se mostra ligada não a um desnudamento do real, mas a uma codificação-prescrição na formulação do verdadeiro;

7. Pela razão não se torna evidente o sujeito, o homem e, de resto, nem respostas definitivas para o problema da moral;

8. Sobre a visão foucaultiana geral acerca da razão na história, ele acha já termos ultrapassado o momento de uma razão analítica, dialética depois, restando hoje a necessidade de uma razão voltada para saber o que nos impõe, para saber como poderemos "funcionar", algo que se precisa talvez fazer frente através da crítica;

9. Destacou-se acima talvez porque uma crítica a ser feita nada garante, pelo menos até agora, a chegada para um porto seguro sem reservas, haja vista a própria tarefa do ato de escrever, ou do ato de se pronunciar acerca de algo. Um escrito, para Michel Foucault, não pretende ser prescritivo; ao contrário, as pessoas devem 'não saber mais o que fazer' ...; os escritos devem causar nelas uma certa "paralisia", não entendida aqui como alguma forma de "anestesia". Em um caso, algo me tocou, algo está forçando o pensamento a pensar; ${ }^{60}$ no outro caso, perco os movimentos, fico sem ação. Mas o passo seguinte à paralisia não implica em, retomando alguma espécie de razão apurada, tornar o crítico um "reforma-

60 Heidegger (1959, p. 24) disse a esse propósito: “O que dá mais a pensar hoje é que nós não pensamos ainda". 
dor", com suas funções "proféticas ou legislativas" (FOUCAULT, "Table ronde du 20 mai 1978", DE, IV, 1994, p. 34). Até porque Foucault defende a ideia de que "O que é mais perigoso na violência é a sua racionalidade". E se não há incompatibilidade entre ambas, diz que seu problema foi "determinar a natureza dessa racionalidade que é tão compatível com a violência" (FOUCAULT, "Foucault étudie la raison d'État", DE, IV, 1994, p. 38-39).

Ora, a crítica, como inversão de todas essas visões por demais românticas acerca do conhecimento e da racionalidade em Foucault precisaria, talvez, fornecer uma visão agora "positiva" acerca da saída humana quase dessa menoridade, nas palavras de Kant, na qual estamos envoltos, se se puder falar dessa forma. Só que Foucault não ancora, como em Kant, em uma razão ciosa dos seus limites, precisando desenvolverse até essa linha limítrofe, muito menos nos discursos mais socialmente legitimados, como o científico (o caso da Física valorizada por Kant).

Até o personagem conceitual de "crítico" não se obteve respostas mais contundentes acerca da saída do círculo do saber-poder, e por dois motivos: primeiro, a conferência de 1978 ("Qué es la Crítica? [Crítique y Aufklärung]") termina com sugestões de método; são atitudes ou movimentos críticos que as pessoas deverão fazer por sua conta, tendo em vista, obviamente, as recomendações de Michel Foucault; em segundo lugar, até a sua morte, em 1984, ele menos retoma o projeto crítico esboçado na conferência supra, do que irá concentrar-se na sua chamada última fase, a da genealogia da ética. 
Kraemer não olvida as dúvidas acima que podem pairar, e reproduz uma interrogação que pode vir à baila muito facilmente, em se pensando na démarche de Michel Foucault:

Mesmo considerando-se o caráter de Crítica e de denúncia, presentes nos domínios arqueológicos e genealógicos, facilmente eles deixam a impressão de que o indivíduo é simplesmente um efeito da épistémè e dos dispositivos, uma subjetividade constituída enquanto efeito das práticas de saber-poder, simples determinação, sem Abertura ao possível e à autonomia do sujeito. [...] Nada pode nos salvar de nós mesmos, da repetição das verdades que nos constituem, nos submetem, nos governam (KRAEMER, 2011, p. 275).

Para autores como Gilles Deleuze, porém, a interpretação a ser dada tem a ver com o seguinte: a nova fase de Foucault traz, ao contrário do que se poderia pensar, um olhar positivo: após ter relacionado e estudado o saber e o poder, "Foucault chega a um impasse [...]. Seria como um novo eixo distinto ao mesmo tempo do eixo do saber e do eixo do poder. Eixo no qual se conquista uma serenidade? Uma verdadeira afirmação de vida?" (DELEUZE, 1988, p. 103). Um passo necessário, pois, e afirmativo, para Deleuze.

Sinal "constitutivo dessa consciência decepcionada com o esclarecimento" (BICCA, 2011, p. 167)? Pouco se pode fazer a não ser partir para algumas conjecturas, embora todas elas acima mencionadas sejam plausíveis. De qualquer forma, o fato é que Michel Foucault, como foi dito, não leva avante o 
pensamento crítico e, ao direcionar-se para uma nova fase, isso por si só já legitima esforços no sentido de perceber a construção desse novo personagem conceitual denomidado de "esteta". Compreende-se isso como um momento complementar, uma formação híbrida então instituída entre o crítico e aquela nova imagem. O foco tácito do que se dirá a seguir residirá na pergunta: como realizar atitudes?

Há vários temas que merecem relevo nesse novo plano da genealogia da ética instaurado por Foucault, embora, tradicionalmente, duas temáticas são demarcadas: o "cuidado de si" (a extensão, no plano da ética, do não querer ser governado, ou seja, de buscar governar-se a si mesmo) e a "estética da existência". É preciso, porém, ao lado disso não descuidar de algumas outras temáticas que gravitam em seu entorno. Elas vão perfazer uma outra tríade relacionada ao sujeito: verdade-poder-corpo. São questões que Foucault termina seguindo quando for propor uma "atualização" da sua ética, baseada nos acontecimentos hodiernos, desde o que se chama aqui de cinismo mitigado, até os temas específicos ligados à homossexualidade e ao sado-mazoquismo. Ou seja, questões que têm a ver com corpo e "sexualidade".

Mas por que sujeito novamente? Michel Foucault estaria fazendo um "retorno" a este, e daí a razão do seu olhar retrospectivo, segundo o qual a verdadeira linha do seu pensamento estava voltada para tal temática? É verdade que ele encobre um pouco o estudo acerca do poder, seja através do modelo jurídico (sujeito portador de direitos e deveres), seja do modelo institucional, e parte para estudar as formas pelas quais um sujeito pode ser objetivado (FOUCAULT, “Le sujet et le pouvoir", DE, IV, 1994, p. 224). Mas, realizando algo como 
uma "história da 'subjetividade", sua meta foi buscar perceber "a maneira pela qual o sujeito faz a experiência de si mesmo num jogo de verdade onde ele tem relação a si" (FOUCAULT, "Foucault", DE, IV, 1994, p. 633). Ora, é dessa independência entre eles (sujeito e objeto, entendidos como processos de objetivação e de subjetivação, como visto), é dessa reciprocidade que nascem os jogos de verdade; quer dizer, não coisas em si mesmas verdadeiras ou falsas, mas coisas que, submetidas a certas regras, aparecem com o estatuto de verdadeiras ou falsas (FOUCAULT, “Foucault”, DE, IV, 1994, p. 632).

É verdade ainda que, pensando no seu percurso, diz ter buscado o sujeito apreendido a partir do estatuto do conhecimento científico - o sujeito falante, trabalhador e vivente -; depois, o sujeito normatizado - o louco, o doente e o delinquente -; depois, o sujeito como objeto para si mesmo, com sua tarefa de decifração, análise, objeto de observação de si e de reconhecimento dentro de um saber possível. Daí Foucault concluir textualmente: "Não é, portanto, o poder, mas o sujeito, o que constitui o tema geral de minhas pesquisas" (FOUCAULT, “Le sujet et le pouvoir”, DE, IV, 1994, p. 223).

Não se acredita aqui, porém, que isso possa levar ao que pensou François Dossê. Em seu livro Histoire du structuralisme ele conclui a sua redação sobre a parte endereçada a Foucault dizendo sobre certo retorno de Foucault a Sartre, a partir da questão do sujeito, que é reintroduzido:

Esse desvio pela Grécia e por Roma remete, por conseguinte, em grande parte, ao não-dito do indivíduo Foucault, à sua busca desesperada e urgente de uma ética, de uma ascese espiritual compensatória de 
um desprendimento próximo de seu corpo, de uma libertação da culpabilidade mortífera que o habita, e de uma reconsciliação final consigo mesmo. Decididamente, o sujeito está de volta (DOSSÊ, 1994, p. 389).

Ora, não há contradição entre o que asseverou mais acima Foucault e o que escreveu Dossê, apenas uma não atenção deste a um detalhe: a volta foucaultiana ao sujeito nada tinha a ver com a imagem que boa parte da tradição filosófica fez deste: uma instância soberana, em suas mais diversas situações. Na nova fase de Michel Foucault a questão é fazer uma "ontologia histórica de nós mesmos" - mas isso, tendo em vista o amplo horizonte no qual nos constituímos como sujeitos de nosso saber, como sujeitos agentes ou pacientes do poder e, finalmente agora, nessa nova fase, como sujeitos morais de nossas ações (FOUCAULT, “Qu'est-ce que les Lumières?”, DE, IV, 1994, p. 574).

Há de se referir então àquela tríade relacionada ao sujeito: verdade-poder-corpo. O corpo, para Foucault, vai estar no centro do problema da moral. Se se fala em evolução moral, fala-se diretamente da "evolução" no trato para com o corpo, escreve ele em 1972 (FOUCAULT, “La société punitive”, DE, I, 2001, p. 1337). Fora os estudos relacionados com o corpo do louco e o do doente, Foucault falara depois, em Surveiller et punir, da passagem do corpo supliciado ao corpo adestrado, ou seja, desse corpo utilizado e pensado como "força de trabalho" (FOUCAULT, “Sexualité et politique”, DE, I, 2001, p. 1405), e essa problemática vai continuar nos dois outros volumes da sua Histoire de la sexualité, a saber: "Essa luta pelo corpo [...] que faz da sexualidade um problema político" (FOUCAULT, "Sexualité et politique", DE, I, 2001, p. 1405). Daí a posição de Giacóia: menos buscar fazer uma história das morais, buscou 
ele fazer uma "genealogia do corpo como corpo de ações éticas" (GIACOÍA JÚNIOR, In: MARIGUELA, Org., 1995, p. 90).

Mas, agora, é uma problemática não referente às interdições, à história dos sistemas de moral, mas às "práticas de si", que aparecerá nessa fase da ética, tanto em L'usage des plaisirs (2003d), quanto em Le souci de soi (2002c), além das entrevistas e prefácios contidos nos Dits et écrits e dos cursos no Collège de France de 1981 a 1984, como L'herméneutique du sujet (2001). Ou seja, Foucault vai se referir não mais aos gestos de partilha da sociedade, como no caso da loucura e sanidade, dos doentes ou sãos, dos delinqüentes ou cidadãos, mas às "transformações em nossa cultura das 'relações a si mesmo', com sua armadura técnica e seus efeitos de saber" (FOUCAULT, "Subjectivité et vérité", DE, IV, 1994, p. 214). ${ }^{61}$ Um estudo que, mais uma vez, quer se concentrar não em uma hipótese repressiva em torno do "desejo", senão em uma pesquisa centrada nos atos e prazeres, na aphrodisia grega (FOUCAULT, “Subjectivité et vérité", DE, IV, 1994, p. 215).

É no âmago de uma pesquisa acerca da "sexualidade" que será desenvolvida a sua genealogia da ética e os temas da moral e da ética, aparecendo estas logo nas primeiras páginas de L'usage des plaisirs. Saiba-se, porém, para entendimento geral do seu projeto, que Foucault está pensando em fazer um estudo sobre a história da "sexualidade" com características próprias. Como ele mesmo alertou, não se trata de uma história dos "comportamentos", das "representações" ou então

61 Essa mudança de perspectiva: de uma "genealogia tipológica das diversas formas de moral, e não uma genealogia da ética entendida como rapport à soi" - marcaria uma diferença de Foucault em relação a Nietzsche (GIACOÍA JÚNIOR, In: MARIGUELA, org., 1995, p. 93). 
das "condutas" e "práticas sexuais" segundo sua sucessão, evolução e difusão; muito menos de analisar as idéias científicas, religiosas ou filosóficas "através das quais foram representados esses comportamentos" (FOUCAULT, 2003d, p. 9). Trata-se antes de questionar a "sexualidade" como tradicionalmente se fez (palavra, aliás, nascida tardiamente - século XIX), questioná-la a partir de certas limitações históricas e de domínio, ${ }^{62}$ e no cerne da sua evidência "familiar". Em suma, como abordar a "experiência" da sexualidade?

Ou ainda, escreve Foucault, como "o homem ocidental foi levado a se reconhecer como sujeito de desejo" (FOUCAULT, 2003d, p. 12)? E por que, aliás, o comportamento sexual e os prazeres relacionados com este foram objetos de uma preocupação moral tão incisiva desde aquele tempo antigo? As alternativas para tal estudo eram ou fazer um inventário, um "exame histórico" do desejo segundo as épocas, ou recortar genealogicamente a lenta formação, desde a Antiguidade, de uma "hermenêutica de si" (FOUCAULT, 2003d, p. 13). A opção de Foucault foi na direção desta segunda opção.

É importante aqui deslindar as principais ideias foucaultianas contidas nos dois últimos livros da sua histoire de la folie, uma vez que muitos elementos importantes para a compreensão da sua ética vão estar contidos aí.Em L'usage des plaisirs Foucault diferencia o significado de moral e ética da seguinte forma: a moral seria "um conjunto de valores e regras de ação propostos aos indivíduos e aos grupos por intermédio de aparelhos prescritivos diversos", como família, escola, igreja etc.

62 Limitação histórica: Foucault vai estudar o tema tomando por base a Grécia clássica e os séculos I e II d.C.; limitação de domínio: focalizará o problema das técnicas da vida em torno da aphrodisia, ou atos que dão prazer. 
(FOUCAULT, 2003d, p. 36-37), ora sendo formulado por doutrinas coerentes e ensino explícito, ora transmitido de maneira difusa, permitindo aí haver a opção do compromisso com ela ou do não-compromisso, da "escapatória". O código moral é o conjunto prescritivo; a moral diz respeito também à maneira como cada um se comporta na realidade, submetendo-se às prescrições ou as recusando por resistência, negligenciando-as. A esse grau de variação Foucault denomina "'moralidade dos comportamentos'"' (FOUCAULT, 2003d, p. 37).

Em cada preceito moral, por exemplo, a fidelidade como norma, cada um pode "se conduzir" de diferentes maneiras. Foucault chama isso de "determinação da substância ética'" (FOUCAULT, 2003d, p. 37), ou seja, "a maneira pela qual o indivíduo estabelece sua relação com essa regra e se reconhece como ligado à obrigação de pô-la em prática" (FOUCAULT, 2003d, p. 37). Em cada caso também existem diferentes formas de "elaboração do trabalho ético", não só para se conformar a uma regra, mas igualmente "para tentar se transformar a si mesmo em sujeito moral de sua própria conduta" (FOUCAULT, 2003d, p. 37-38). Foucault vai inserir aí o conceito de "teleologia do sujeito moral": uma ação não visa a ser apenas algo que está em conformidade com uma regra, ela visa da mesma maneira a marcar tal sujeito em seu modo de ser próprio (FOUCAULT, 2003d, p. 39). É que uma ação moral, não implicando apenas aquela correspondência, aponta de forma implicativa também para uma relação a si que não é tão somente consciência de si, mas "constituição de si como "sujeito moral'" (FOUCAULT, 2003d, p. 40). Para tanto, deve tal sujeito realizar "práticas de si" diversas, como conhecer-se, controlar-se, pôr-se a provas, aperfeiçoar-se, transformar-se etc. (FOUCAULT, 2003d, p. 40). 
Assim, haveria uma história das moralidades: a conformidade dos indivíduos às regras no tempo; uma história dos códigos: as regras e valores que em dado momento vigoram, mais os sistemas coercitivos e as contradições e divergências existentes aí; e uma história da ética e da ascética: "história das formas de subjetivação moral e das práticas de si destinadas a assegurá-las" (FOUCAULT, 2003d, p. 41); ou ainda, história da ética como a "elaboração de uma forma de relação consigo que permite ao indivíduo constituir-se como sujeito de uma conduta moral" (FOUCAULT, 2003d, p. 324). Resumindo, toda moral, em sentido amplo, comportaria: 1) os códigos de comportamento; e 2) as formas de subjetivação específicas existentes - ambos não dissociados entre si, mas relativamente "autônomos", como quer Foucault. Davidson, na sua "Introduction" (In: Foucault, 2004, p. 651) resume tudo isso no seguinte gráfico:

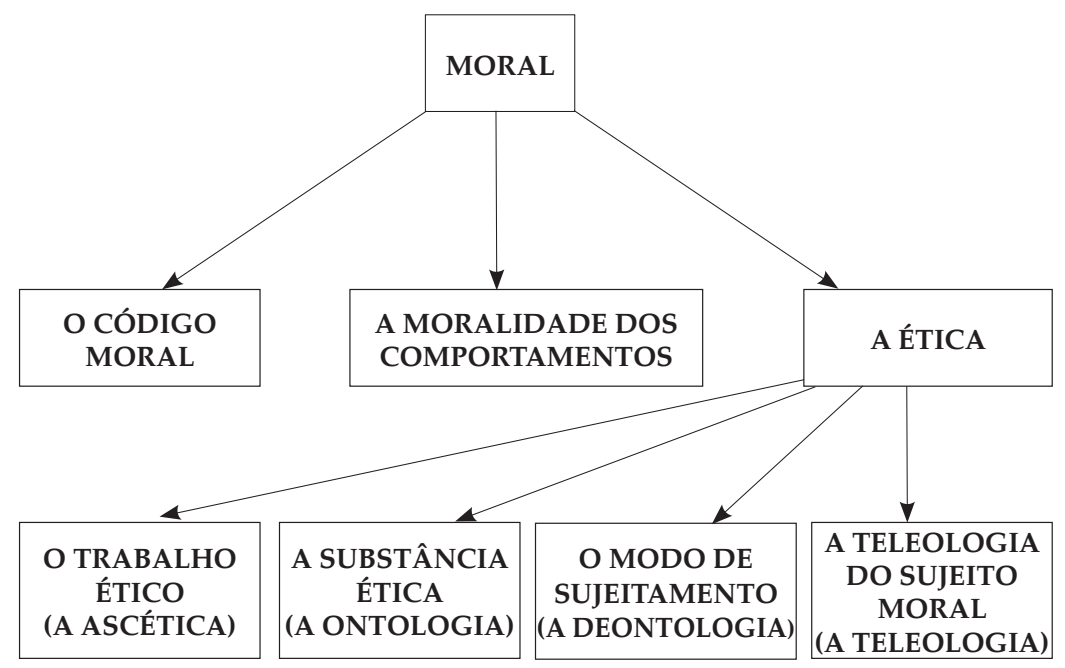


Algo importante acerca de tudo o que foi falado: se em uma dada moral os códigos de comportamento vão sobressair, as "instâncias de autoridade" que devem assisti-lo vão igualmente mostrar-se, impondo aprendizagens e observação em relação a eles e determinando punições aos infratores. Foucault escreve: "nessas condições, a subjetivação se efetua, no essencial, de uma forma quase jurídica, em que o sujeito moral se refere a uma lei ou a um conjunto de leis às quais ele deve se submeter sob pena de incorrer em faltas que o expõem a um castigo" (FOUCAULT, 2003d, p. 42). Mas, obviamente, como interpreta Gadelha, não são condutas forçadas o que está em causa, senão formas pelas quais o sujeito introjeta ideias e comportamentos. Em suma, falar em processos de subjetivação é pensar na "constituição de identidades, de personalidades, de formas de sensibilidade, de maneira de agir, sentir e pensar, normalizadas, sujeitadas, regulamentadas, controladas" (GADELHA, 2009, p. 173).

Talvez essa distinção inclinasse Foucault a reservar tanto tempo no estudo do pensamento antigo. Se a moral cristã não poderia ser reduzida apenas àquele modelo prescritivo, algo que seria "totalmente inexato" (FOUCAULT, 2003d, p. 42), por outro lado a moral grega e grego-romana deram primazia às formas de subjetivação e práticas de si, sendo "rudimentar" nesse período o "sistema dos códigos e das regras de comportamento", das "codificações da conduta", da catalogação do permitido e do proibido (com exceção de A República e as Leis, de Platão) (FOUCAULT, 2003d, p. 42-43).

Daí Foucault se deter no plano da ética, que o levou a classificar e a distinguir em relação ao cristianismo e ao pensamento antigo as diversas relações para consigo; a saber, "substância 
ética" (aphrodisia ou atos que proporcionam prazer para os gregos, versus concupiscência, para os cristãos); "tipos de sujeição" (chresis ou saber-fazer versus atenção a regras universais); "formas de elaboração de si" (enkrateia ou domínio de si versus renúncia a si); "teleologia moral" (sophrosune ou temperança, como liberdade alcançada "pelo exercício do domínio [de si] e pelo comedimento na prática dos prazeres", versus a busca pela salvação - FOUCAULT, 2003d, p. 107).

Em outro momento Foucault vai especificar a importante noção de sujeito moral na relação a si segundo quatro características pouco diferentes das que foram dadas acima, mas com algumas outras explicações. A saber: 1) que há um campo de moralidade (o desejo para o cristianismo, a intenção para Kant, o bom sentimento, hoje em dia); 2) o modo de "sujeição" (a maneira de se "convidar" ou de se "incitar" alguém a "reconhecer suas obrigações morais"; 3) os meios para a transformação da pessoa em sujeito moral; 4) a teleologia, ou tipo de ser que se deseja tornar no plano da moral (FOUCAULT, “À propôs de la généalogie de l'étique: um aperçu du travail em cours", DE, IV, 1994, p. 395).

O código é aquilo que interdita e, se Foucault vai se deter mais em uma história da relação do sujeito a si é porque os códigos, segundo ele, pouco mudam. Ao mesmo tempo, cada sociedade na história se vale mais ou menos da força imperativa da lei ("À propôs de la généalogie de l'éthique: un aperçu du traavail en cours", DE, IV, 1994, p. 396-397). Estaria nessa valorização de um sistema mais aberto e menos codificado, encontrado na Antiguidade pagã, a aproximação da visão de alguma espécie de liberdade moderna, no pensamento foucaultiano? Os gregos e grego-romanos elaboraram uma "arte 
da existência", ou seja, práticas refletidas e voluntárias com as quais fixaram regras de conduta, tentaram modificar o seu ser e fizeram da sua vida uma obra portadora de valores estéticos e de estilos próprios.

Isso não significa, porém, que a moral cristã foi marcada pela repressão e a grega e helenística pela liberdade. A novidade da moral cristã não foi ter introduzido novos interditos éticos, mas novas técnicas e mecanismos de poder. É nesse momento que o tema da "pastoral cristã", ou "tecnologia pastoral" novamente ganha sua importância no pensamento de Foucault. Ele aponta algumas características, complementando o que já se disse no segundo Capítulo desta tese: 1) o poder pastoral é essencialmente religioso; 2) seu objetivo é não-terrestre, pois visa a salvar a cada um e a todos (dar segurança contra os reveses da vida), ao invés de salvar um rei, um Estado ou um território específico; 3) salva por "benevolência", sendo mesmo um dever fazer isso, tomando em suas mãos o destino dos fiéis; 4) reclama obediência e dependência completa do "rebanho" ao pastor (uma das diferenças radicais com relação aos gregos) (FOUCAULT, "'Omnes et singulatim': vers une critique de la raison politique", DE, IV, 1994, p. 147); 5) suas técnicas (direção espiritual, cuidado ou atenção às almas) têm efeitos individuantes, procedimentos de individuação que, a partir do século XVIII, foram seguidos pela sociedade capitalista, industrial e pelas formas modernas de Estado (FOUCAULT, "La philosophie analytique de la politique”, DE, III, 1994, p. 550).

Entenda-se aqui individuação como a obrigação de encontrar em si mesmo a verdade de si através da confissão, ocasionando uma mudança de comportamento (FOUCAULT, "La 
philosophie analytique de la politique", DE, III, 1994, p. 549 e FOUCAULT, "'Omnes et singulatim': vers une critique de la raison politique", DE, IV, 1994, p. 137-139), e por prolongamento dessa tendência religiosa aquilo que, após a Idade Média, tornou-se uma finalidade geral: "conduzir e dirigir o homem ao longo da sua vida e em cada uma das circunstâncias dessa vida" (FOUCAULT, "La philosophie analytique de la politique", DE, III, 1994, p. 549). Assim, como pensar que o Estado ignora o indivíduo? Ao contrário, a nova "Razão de Estado" que se forma a partir da primeira metade do século XVII transformou o governo cristão das almas em governo dos homens (FOUCAULT, "Sécurité, territoire et population", DE, III, 1994, p. 720).

Mas o que se pretende enfatizar nesse momento é a compreensão de que com o poder pastoral as "artes da existência" ou as "técnicas de si" - tema este através do qual Foucault vai debruçar-se sobre uma "história da subjetividade" (FOUCAULT, "Subjectivité et vérité", DE, IV, 1994, p. 214) - perderam parte da sua importância e autonomia, embora autores como Burckhardt ou Benjamin tentassem resgatar isso nos seus estudos (FOUCAULT, 2003d, p. 18). Pois se Habermas falara em três tipos de técnicas: de produção, de significação ou comunicação e de dominação - Foucault vai reclamar uma terceira: as técnicas de si, que implicam uma "série de obrigações de verdade", ou seja, descobri-la, ser iluminado por ela e dizê-la, como encontrada no cristianismo, através dos dogmas, da Bíblia e dos ditames dos pastores (FOUCAULT, "Sexualité et solicitude", DE, IV, 1994, p. 170-171).

Segundo a interpretação de Foucault, baseada em um catolicismo clássico, o sexo e o seu nexo com o prazer se tornara ontologicamente um mal, pois fruto de uma "queda" 
ou "falta" (o pecado de Adão), determinante da natureza humana; o uso dos prazeres é regido por regras ou normas universais, vindas da Bíblia, e pela interpretação do pastor; a renúncia a si dá-se pela elucidação e renúncia dos desejos, pela decifração daquilo que está internamente no sujeito, com vistas à purificação.

Ou seja, enquanto que na Antiguidade a relação de luta consigo mesmo (enkrateia) deveria dar-se pelos pares 'dominação-obediência', 'comando-submissão', 'domínio-docilidade', no cristianismo os pares são 'elucidação-renúncia', 'decifração-purificação' (FOUCAULT, 2003d, p. 95). De qual liberdade é possível encontrar segundo tais inclinações? Não uma liberdade no sentido de fazer de cada um senhor dos seus prazeres para daí facultar a prática do bem, exercendo domínio sobre si mesmo e sobre os outros, ideia foucaultiana retirada de Xenofonte (FOUCAULT, 2003d, p. 106); ao invés, uma liberdade coercitiva, que tenta conduzir cada um ao reencontro de uma inocência de origem, de uma pureza alhures, eximindo-os da mácula; ou mesmo a uma "liberdade constrangida": 1) faze o que é necessário, ou serás punido; 2) faze segundo uma obediência à autoridade do pastor; 3) que tal obediência seja absoluta; 4) saiba que o pastor ensina a verdade, e que dele e da Bíblia decorrerão o conjunto de preceitos a seguir (FOUCAULT, "La philosophie analytique de la politique”, DE, III, 1994, p. 564).

Em todo esse processo o Ocidente cristão inventou a "surpreendente coação" de impor a cada pessoa o ato de confessar a mínima falta, que se somou à prática da instituição judiciária e seus interrogatórios, dossiês etc. No cristianismo, as práticas e cuidados de si gregos darão lugar ao cuidado dos outros, das almas (FOUCAULT, “À propôs de la généalogie de 
l'étique: um aperçu du travail em cours", DE, IV, 1994, p. 409). No caso da virtude sexual grega baseada naquele domínio, e no princípio do homem viril (tal virilidade é que vai importar na relação entre parceiros do mesmo sexo, segundo Foucault), passa-se em seguida para uma virtude sexual endereçada à jovem ou mulher casta, virgem e fiel (FOUCAULT, 2003d, p. 111). Em suma, a verdade das coisas em geral, alcançada pelo homem temperante através do exercício do ortho logos, da justa razão, passa à questão da verdade do homem alcançada pela confissão sobre os deslizes da alma em relação aos impulsos da carne, às vezes tendo que se humilhar ou se autopunir.

A temperança implica quatro coisas, na verdade fundamentais para que Foucault caracterize o modo grego de estética da existência: 1) que o logos (na prática dos prazeres) seja soberano, submetendo os desejos e o comportamento (forma estrutural); 2) dominando os prazeres realça-se uma razão prática: fazer, segundo Aristóteles, "o que se deve, como se deve e quando se deve'" (forma instrumental); 3) "a necessidade de se conhecer a si mesmo, a fim de praticar a virtude e dominar os desejos", como disso fala Platão no Fedro (reconhecimento ontológico de si por si); 4) uma relação com a verdade fazendo surgir não uma hermenêutica do desejo (como no cristianismo), mas uma estética da existência. Quer dizer, menos uma vida conforme a códigos, leis ou trabalho de purificação de si, do que uma vida que leva em conta "certos princípios formais gerais no uso dos prazeres, na distribuição que deles se faz, nos limites que se observa, na hierarquia que se respeita" (FOUCAULT, 2003d, p. 120).

O modo de sujeição do cristianismo relativo ao comportamento sexual, baseado nos ditames da Bíblia e de seus representantes, na pesquisa pelos maus desejos de cada um, "por 
um conjunto de atos cuidadosamente definidos em sua forma e em suas condições" (FOUCAULT, 2003d, p. 124), ao se contrastar com o saber-fazer pagão, mostrava que doravante o Ocidente oporia o caráter legislativo universal a uma conduta antiga baseada em uma arte toda especial. Saber-fazer, saberviver para os gregos (não todos, mas os bem nascidos, pelo menos na Grécia clássica) era uma arte, o momento em que cada um se via diante de situações e necessidades as mais diversas (sempre relativas ao seu status, até antes do período helenístico) e deveria, livremente, posicionar-se diante delas (FOUCAULT, 2003d, p. 123).

Foucault fala aqui precisamente em "estilização da atitude" e em "estética da existência", termos que às vezes praticamente se equivalem (embora uma 'moral de estilo' só vá aparecer mesmo nos séculos II e III d.C., para ele). ${ }^{63}$ Quanto à estilização da atitude, ainda não falada, consiste na idéia de que

[...] a rarefação da atividade sexual se apresenta como uma espécie de exigência aberta: [...] nem os médicos, nem os moralistas, nem aqueles que dão conselhos sobre a boa conduta dirão exatamente o que é preciso ou não fazer na ordem dos atos ou práticas sexuais. E a razão disso [é que...] a temperança sexual é um exercício da liberdade que toma forma no domínio de si (FOUCAULT, 2003d, p. 125).

63 Para Sandra Coelho de Souza (SOUZA, 2000, p. 825) a ética em Foucault "rima também com 'estética', e é justamente esse potencial de sentido que segundo Focault pode tornar a razão pouco atraente". 
Foucault, em L'usage des plaisirs, vai falar em estilização na dietética, na econômica e na erótica; respectivamente, o homem no cuidado para com o seu corpo, o homem como chefe de família e o homem na relação com os rapazes (FOUCAULT, 2003d, p. 127-292). Deve-se passar aqui ao largo disso em suas minúcias, retendo apenas que, se os atos sexuais não são algo de ruim por natureza, claro, tudo depende do seu "uso". Não há uma desqualificação ética como no cristianismo, ao privilegiar apenas o caráter procriador na prática sexual. Além disso, se há obviamente conselhos que apontam para certas austeridades, aî "não somente os gregos não buscaram definir um código de conduta obrigatório para todos, como também não procuravam organizar o comportamento sexual como um domínio dependente em todos os seus aspectos a um único e mesmo conjunto de princípios" (FOUCAULT, 2003d, p. 324).

E se se pode falar em "sujeito", no seu sentido mais forte, este teve a ocasião de se mostrar justamente no mundo grego, na medida em que cada um se torna livre por suas escolhas, e na medida em que tais escolhas vão determinar "quem" conseguiu tornar-se "o quê". Na Grécia clássica, sobretudo, o sujeito que se valoriza, aquele que pode dominar a si e aos outros o faz não porque se adequou a leis ou princípios pré-estabelecidos, mas quando conseguiu atingir aqueles referidos domínios, através de escolhas e esforços próprios. Nesse sentido, uma estética da existência elaborada pelos homens adultos livres consistirá em uma "arte refletida de uma liberdade percebida como jogo de poder [e em uma ética sexual] problematizada no pensamento como a relação, para um homem livre, entre o exercício de sua liberdade, as formas de seu poder, e seu acesso à verdade" (FOUCAULT, 2003d, p. 326). 
Algo totalmente diferente ocorreu com o cristianismo. A investigação sobre o sujeito passou por uma vontade de saber toda peculiar, na qual a verdade do nosso sexo terminava indo para além disso; a nossa sexualidade deve apontar a uma verdade sobre o sujeito. Torna-se isso uma espécie de coerção. E, com efeito, escreve Sandra Coelho de Souza,

Se Foucault dá uma grande importância ao fato de que, na Antiguidade clásssica, a prática sexual não obedecia nem à coerção de um código que tivesse prescrito condutas a observar, nem a uma hemenêutica do sujeito, ele o faz a fim de mostrar melhor a separação profunda entre a moral, assim concebida, e a que foi adotada pela pastoral cristã, inteiramente orientada a uma 'codificação dos atos sexuais [...] e o desenvolvimento de uma hermenêutica do desejo e dos procedimentos de decifração de si' (SOUZA, 2000, p. 707).

Daí Foucault insistir na idéia de que a sociedade atual não conduziu o homem para uma repressão do sexo, senão para uma "'expressão'" deste, um poder-incitação ou podersaber (FOUCAULT, "L'Occident et la vérité du sexe", DE, III, 1994, p. 103). Os movimentos homossexuais não incorrerão em erro, justamente por tentar atrelar o "quem?" que cada um deve ser, a esse caráter (homo) sexual? L'usage des plaisirs termina fazendo uma breve referência a mudanças no âmbito do prazer (mais precisamente, a uma estética do uso grega, para repousar agora no aspecto do desejo, "com sua hermenêutica purificadora"). Esta técnica de interpretação será realçada pelo cristianismo, embora já pronunciada nos século I e 
II d.C., objeto de estudo foucaultiano da última parte publicada da sua Histoire de la sexualité.

Le souci de soi, o terceiro volume, começa com uma análise acerca de Artemidoro (século II d.C.) e sua interpretação dos sonhos. O intuito: "decifrar a moral que está subjacente às análises dos sonhos sexuais" (FOUCAULT, 2003d, p. 18). Mas, como na Grécia clássica, o que vai marcar os séculos I e II d.C. não será uma intensificação sobre o sexo, mas um cuidado de si, uma "vigilância" ou uma "inquietação" no que diz respeito aos distúrbios do corpo e da alma, distúrbios que é preciso evitar, através de um regime de austeridade (FOUCAULT, 2002e, p. 56).

Austeridade, bem entendida, jamais passível de confusão com lei ou interdição. No cristianismo, a fidelidade conjugal, por exemplo, será um verdadeiro dever a ser seguido, se se quer a salvação. Já anteriormente, como em Plutarco, embora houvesse indicações acerca do permitido ou do proibido na vida do casal, não o seria fruto de uma "regulamentação", mas em função de

[...] uma maneira de ser, um estilo de relações; a moral do casamento e os conselhos sobre a vida conjugal são, ao mesmo tempo, princípios que valem universalmente, e regras para aqueles que querem dar `a sua existência uma forma honrada e bela. É a universalidade sem lei de uma estética da existência que, de todo modo, só é praticada por alguns (FOUCAULT, 2002e, p.246). 
Ter cuidado consigo mesmo, ocupar-se de si: os greco-romanos vão chamar isso de heautou epimeleisthai, e tal será o princípio que vai reger a arte da existência, ou techne tou biou. Caberá aos dois primeiros séculos da nossa era, por exemplo em Epicteto, levar esse imperativo adiante, ao definir o ser humano como aquele ser destinado ao cuidado de si (FOUCAULT, 2002e, p. 65). Mas Foucault mostra como houve uma diferença entre o "exame" socrático-platônico ao exame que aparece naquela idade de ouro do epimeleisthai. No primeiro caso, que pode ser ilustrado pelo Alcebiades de Platão, ocupar-se de si era uma atividade bastante particular, reservada aos jovens aristocratas "destinados a exercer o poder"; segundo, exercer como se devia, ou seja, de forma racional e virtuosa; terceiro, o cuidado de si implicava em um conhecimento de si. Quando o helenismo aparece algumas diferenças vão sobressair, e também enumeradas segundo três deslocamentos:

Primeiramente, cuidar-se de si tornou um princípio geral e incondicional, um imperativo que se impõe a todos, todo o tempo e sem condição de status. Segundo, cuidar-se de si parece não ter mais razão de ser uma atividade bem particular, aquela que consiste em governar os outros [na cidade] [...]. Enfim, terceiro traço, que o cuidado de si só se determina mais manifestamente na única forma do conhecimento de si (FOUCAULT, 2001, p. 81). 
Não haveria, porém, malgrado tais diferenças, uma ruptura com a ética anterior, senão uma diferença de acento, ilustrada pela moral sexual:

\begin{abstract}
A moral sexual exige ainda e sempre que o indivíduo se sujeite a uma certa arte de viver que define os critérios estéticos e éticos da existência; mas essa arte se refere cada vez mais a princípios universais da natureza ou da razão, aos quais todos devem se curvar da mesma maneira, qualquer que seja seu status (FOUCAULT, 2002e, 93).
\end{abstract}

O status cede lugar ao respeito a si como ser racional, em uma "intensificação da relação consigo pela qual o sujeito se constitui como sujeito de seus atos" (FOUCAULT, 2002e, p. 57). A articulação anterior entre o poder sobre si e o poder sobre os outros se desloca, ou melhor, cede em sua importância, já que agora o ato em si mesmo não precisa se referir de imediato à condição sócio-política de cada um.

Encontra-se aqui diante de uma série de interpretações foucaultians que expandem o sentido daquela "atitude" referida no início deste Capítulo. Foucault teria razão nas suas colocações? Há aí uma questão de adequação interpretativa àquilo que estaria, de fato, presente na época e nos autores trabalhados por ele, e uma questão de tomar as suas análises, de qualquer forma, como pontos valorizados por ele, e que comporiam sua "assinatura" filosófica.

Sobre a primeira questão, em "O sujeito antigo de uma época moderna" Pradeau dá certa razão a autores como 
Hadot, segundo a qual Foucault teria negligenciado, na "determinação estética da relação consigo mesmo", inúmeros aspectos importantes:

No essencial, P. Hadot reprova o fato de Foucault ter restringido, de maneira excessiva, a cultura de si a um cuidado de si, a um prazer tomado em si mesmo, negligenciando que a transformação de si significava para todos os antigos não um dobrar-se sobre si, mas, ao contrário, uma transcendência de si e uma universalização para os quais 'o sentimento de pertinência a um Todo', diz P. Hadot, 'me parece ser o elemento essencial (PRADEAU in: GROS, Org., 2004, p. 138)

Outro crítico com posição similar, apontado por Pradeau, foi Cambiano. Para este,

Por não querer reconhecer o caráter crítico e 'subversivo' dos modos de vida propostos pelas escolas filosóficas, Foucault superavaliou a amplitude da liberdade antiga e separou indevidamente, nas doutrinas filosóficas, a ética da cultura de si de seus correlatos teóricos e políticos (PRADEAU In: GROS, Org., 2004, p. 140).

Pradeu, então, conclui provisoriamente que "A ética da história da sexualidade não é a da filosofia antiga"; que não se deve "censurar Foucault", apenas apontar a sua "negligência", por exemplo, em não realçar os "aspectos políticos explícitos da estética da existência platônica ou estóica" 
(PRADEAU in: GROS, Org., 2004, p. 142-143). De qualquer maneira, isso marcaria certa distorção entre uma interpretação de fase específica da história e filosofia do Ocidente com o que ocorreu efetivamente por lá.

Mas, admitindo-se esses excessos interpretativos - aliás, para alguns um procedimento recorrente nos assim chamados filósofos pós-estruturalistas ${ }^{64}$ haveria alguma lição a tirar de tal empreendimento? A resposta de Pradeau foi em dois sentidos. Em primeiro lugar, "seu interesse [o de Foucault] era traçar uma genealogia capaz de servir à elaboração de uma ética contemporânea, de contribuir para o reconhecimento de novas práticas de si"; em segundo lugar, tratava-se de proceder a uma outra tarefa prospectiva: "A reflexão sobre os modos de subjetivação antigos e contemporâneos devia atualizar uma constituição de si estranha ao modelo jurídico, nomonológico, de uma lei geral que se impõe a todos os indivíduos" (PRADEAU in: GROS, Org., 2004, p. 145-146). Esta última ponderação de Pradeau adéqua-se com aquilo falado acima: interpretação correta ou não, o fato é que isso vai servir para Foucault pensar a atualidade.

$64 \mathrm{Ou}$ seja, mais preocupados em reinterpretar livremente os temas dos quais trata do que em fazê-lo buscando um suposto rigor analítico. Assim, cabe nota a polêmica levantada pelo livro Imposturas intelectuais, de Alan Sokal e Jean Bricmont (1999, p. 10), na sua denúncia dos abusos "da terminologia e de conceitos científicos", recaindo no mais das vezes em "relativismos epistemológicos", ao que se acrescenta o livro Pós-Estruturalismo, de James Willians (2012) e Filósofos na tormenta, de Elisabeth Roudinesco (2007). Acerca desta última obra a autora inicia a questão das leituras de Foucault acerca da loucura, pontuando algumas críticas dos "psiquiatras, psicólogos e historiadores da psicopatologia ao livro" foucaultiano, "ao mesmo tempo violenta e ambivalente" (ROUDINESCO, 2007, p. 105). 


\section{A proposta "cínica" e sua atualização}

Em que Foucault se baseou para "atualizar" essa constituição de si, nas palavras de Pradeau, e como modernamente ele se posicionou acerca de inúmeros movimentos sociais de resistência? Se os estudos foucaultianos na sua fase derradeira tomaram por base, positivamente falando, o período da filosofia antiga e cristã até os dois primeiros séculos (quando a pastoral cristã aparece é sempre com uma avaliação negativa), quais as questões que ele privilegiou? A pesquisa de Michel Foucault reenvia, nos seus últimos estudos, para uma "reterritorialização" da ética antiga, aportando no pensamento cínico, e a tese aqui defendida aponta, nessa imagem de certo "cínico" mitigado, para um terceiro traço personalístico a ser somado ao de crítico e ao de esteta.

Já há estudos bem específicos sobre o cinismo grego (BRANHAM; CAZE, 2007) apesar de este, pautado mais na relação do homem com a Physis ou natureza do que no nomos ou costume, as normas sociais da cidade, apesar de ter buscado mais concentrar-se em uma vida a ser vivida do que em uma pesquisa filosófica como tal pouco tenha deixado informações escritas. Como escreveu Luiz Bicca (2011, p. 154), “os cínicos, em geral, não mostravam nenhum interesse por epistemologia, mas muito por questões morais". O propósito aqui não é, assim, fazer um resgate dessa corrente filosófica, mas verificar, nos cursos foucaultianos, o que este autor selecionou da sua importância, como a palavra grega "parrhesía", que Foucault aborda bastante, bem como vários comentadores sinalizam para a importância da noção. Francisco Ortega (1999) reservou boa parte da sua tese de doutorado para 
abordar o problema e o artigo de Frédéric Gros, "A parrhesía em Foucault" (GROS, Org., 2004), dedica-se a falar dele igualmente.

Acredita-se que a conclusão de ambos se assemelha, ou, pelo menos, ambos não deixam de apontar para a importância do "escândalo da verdade" que aparece no texto foucaultiano. Isso será abordado agora, após feita a síntese do entendimento de Foucault acerca da palavra, naquilo que caberá destaque como de fundamental para este trabalho: um momento de crise que ocorreu, aportando no "escândalo da filosofia cínica", objeto de estudo de Foucault desde 1982 (curso de 10 de março), mas com relevo para os cursos proferidos nos idos de 1984, reunidos sob o nome de Le courage de la vérité (2009).

A definição de parrhesía significa "dizer a verdade", falar livremente, "tudo dizer". Na cultura antiga pode-se falar de uma crise da parrhesía e foi esta crise que suscitou de forma vigorosa para Foucault a estética da existência. Se o dizer verdadeiro esteve atrelado, primeiro, a um dizer profético, vindo do oráculo; depois, àquilo que vinha de algum sábio e, por fim, a conhecimentos técnicos transmitidos por quem assim os entendia, uma quarta modalidade antiga de parrhesía surge como "a tomada da palavra pública ordenada à exigência de verdade que, de um lado, exprime a convicção pessoal daquele que a mantém e, de outro, gera para ele um risco, o perigo de uma reação violenta" (GROS, Org., 2004, p. 158).

A crise da parrhesía começou a se dar no século IV socrático, com a crise da democracia. E Sócrates marca aí um momento fundamental nessa "coragem da verdade" ao se recusar ao tudo dizer, sem se valer de um dizer qualquer (tradicionalmente atribuído aos sofistas ou a práticas de 
autofavorecimento por alguns cidadãos ou políticos que discursavam na Ágora). Indo para Platão, o objetivo de Foucault foi realçar as transformações do cuidado de si platônico, na passagem do Alcebíades ao Laques. Segundo Gros, no primeiro caso a filosofia se faz metafísica: "o si que é objeto do cuidado é determinado como alma, enquanto a forma do cuidado se torna a forma do conhecimento" (GROS, Org., 2004, p. 161). Como se encontra no próprio Foucault, mas com outras palavras, o si mesmo é instaurado como "realidade ontologicamente distinta do corpo" - alma, portanto (FOUCAULT, 2009, p. 147); no segundo caso, no Laques,

[...] o cuidado de si não consiste mais em um conhecimento da alma como parte divina em si, mas o objeto do cuidado é o bios, a vida, a existência, e cuidar de si significará dar forma à própria existência, submeter a própria vida a regras, a uma técnica, a pô-la à prova segundo procedimentos: é a filosofia como arte de vida, técnica de existência, estética de si (GROS, Org., 2004, p. 162).

O comentário da passagem de uma obra platônica para a outra, acima referida, encontra-se na lição foucaultiana de 29 de fevereiro de 1984. Mas o objetivo de Michel Foucault vai além delas; ele busca, na verdade, aportar na filosofia cínica, aquela que mais estenderá o cuidado de si com o bios. Foucault adverte: não que ele estivesse defendendo uma "contradição" ou "incompatibilidade" entre ontologia da alma e estética da existência. Apenas quis demonstrar - e para isso toma o exemplo da filosofia cínica - que a "estilística da [existência nunca 
pode ser] a projeção, a aplicação, a conseqüência ou a prática de alguma coisa como uma metafísica da alma" (FOUCAULT, 2009, p. 151).

Ora, como "ressituar o cinismo" na história da filosofia? Um dos caminhos é colocá-lo no âmbito de uma "coragem da verdade". Da "coragem do democrata" - aquela que se manifesta contra opiniões várias nas assembléias - à "bravura do cortesão", podendo contestar o príncipe, Foucault realça uma segunda forma de coragem da verdade fundamental, aquela nascida da ironia socrática, que se arrisca a promover em outrem a "cólera, a irritação, a vingança". Já se conhece melhor essa história, ilustrada pela Defesa de Sócrates (PLATÃO, 1983b), história onde este filósofo é condenado a tomar a cicuta, cujos motivos reais da condenação tinham a ver com o que se falou acima: cólera, irritação e vingança despertada em outrem.

Mas Foucault aponta ainda para uma terceira forma de coragem, esta muito menos conhecida e valorizada, distinta das que foram faladas: a coragem da verdade cínica. O que ela traz de novidade? Quais os seus princípios? Para ele o Ocidente "sempre admitiu que a filosofia não é dissociável de uma existência filosófica" (FOUCAULT, 2009, p. 216). Ou seja, que pensar e agir conforme o pensamento estão presentes a toda hora. Porém, numa referência a Heidegger, se muito relevo se deu a temas como o "esquecimento do Ser" na tradição filosófica, mote do surgimento da metafísica, outro esquecimento pouco comentado foi a questão da "vida filosófica" (FOUCAULT, 2009, p. 218). Daí o realce foucaultiano dado ao cinismo: se nas situações acima relatadas, indo até Sócrates, arriscava-se a vida em se dizendo a verdade, o cínico expôs-se 
ao mesmo risco, mas "não por seus discursos", senão "por sua vida ela mesma" (FOUCAULT, 2009, p. 216).

Essa situação de perigo advem não propriamente ao se seguir quatro dos seus traços principais demarcados por Foucault: ser a filosofia uma preparação para a vida, que implica um cuidado de si e um estudo ou atenção apenas àquilo que é "realmente útil na e para a existência", e viver conforme esses princípios (FOUCAULT, 2009, p. 220). Um quinto princípio cínico "mais fundamental" é destacado por Michel Foucault, e que implicava certa coragem e certo perigo: aquele que aponta para se alterar, falsificar ou mudar o valor da moeda. Conheça a si mesmo e "falsifique a moeda", isso pode ser ilustrado pela "vida de cão" atribuída àqueles seguidores ou, mais especificamente, a Diógenes: um cão vive de forma não pudica (pode cruzar em praça pública); de forma indiferente, precisando apenas satisfazer as suas necessidades imediatas; o cão sabe distinguir os bons, os verdadeiros e os mestres, em relação aos maus, aos falsos e aos inimigos; por fim, relata Foucault, é uma vida de cão de guarda, pois salva e protege a vida dos seus mestres (FOUCAULT, 2009, p. 224).

Uma "vida de cão" faz aparecer, por detrás do "impudor" aparente, uma "vida não dissimulada"; por detrás da sua indiferença, "o retorno escandaloso de uma vida sem mistura", independente e verdadeira. À vida dialética, aquela faz surgir um contraponto: de um lado, do lado dialético, somos reenviados para uma vida ligada ao nomos, à lei e ao direito; do outro lado, do lado do cão, a vida verdadeira aparece como uma vida soberana, onde o domínio de si se destaca de maneira efetiva e imediata (FOUCAULT, 2009, p. 225). Recusam-se aí a seguir hábitos rotineiros que, como tais, são 
ligados às convenções e normas gerais da sociedade. Caso contrário não se estaria falando de autonomia, de relação a si na expressão da palvra. O cínico é, antes de tudo, não um homem da cidade, mas do cosmo.

Na lição foucaultiana da segunda hora, ainda de 14 de março de 1984, cada um daqueles traços (a vida não dissimulada, independente, correta e soberana) são esclarecidos. A vida não dissimulada, a nova estilística da existência cínica, primeiro escândalo, contrasta-se com aquela observada em Platão, Séneca ou Epicteto. Respectivamente, sem se submeter a parâmetros "desonrosos" de conduta, a uma alma que deve separar tudo o que é do âmbito da desordem ou da agitação; do outro (amigo), tomado como guia e testemunho da minha vida; ou do daimon interior que habita em cada um, olhar retrospectivo que se vê, e que mostra a tarefa de viver segundo tal olhar. Ao contrário, no cinismo absolutamente nada é escondido, tudo é publico ou publicizado, seja ao comer, ao fazer as necessidades fisiológicas ou mesmo dar vazão aos desejos (sexuais, por exemplo). Em resumo, escandalosamente, a vida boa é a vida "inteiramente visível" (FOUCAULT, 2009, p. 234).

A vida independente toma a figura da pobreza. Mas de uma pobreza ativa, quer dizer, não propriamente aquela que, possuindo certas condições econômicas favoráveis sabe servir-se dela, ao invés de se tornar servo das coisas as quais possuí. Ou então, como em Sócrates, ser pobre, embora tendo mulher, filhos e uma casa para morar. A pobreza deve ser "efetiva, material, física" (FOUCAULT, 2009, p. 237), além de infinita na sua tarefa: há sempre uma condição mais acanhada de vida por encampar, como em Diógenes, que morava 
dentro de um barril. E que todos possam ver isso, que a visibilidade da pobreza seja percebida sem reservas, até porque nada há para esconder, pelo menos ao mudar os parâmetros de entendimento.

Porque, tomando em consideração o problema dos modelos houve na Grécia uma distinção entre os bons ou melhores, dentro da sociedade, e entre ideais de beleza (do corpo e da alma), de "conduta honrosa" ou "suja" (Saleté). Foucault busca mostrar que, mesmo em Sócrates, a feiúra ou a relativa desimportância dada ao corpo, pelo menos na comparação com a alma, é compensada pela beleza desta na sua elevação. Ora, no cinismo não há essa constante da beleza, que no modelo anterior apenas troca de lugar entre dois pólos, do recrudescimento ou exaltação de uma parte para o declive da outra. "A pobreza cínica, ao contrário, é a afirmação do valor próprio e intrínseco da feiura (laideur) física, da devassidão, da miséria" (FOUCAULT, 2009, p. 239).

Deshonra (déshonneur): este é um desiderato fundamental do cínico; ele a procura a todo o instante, uma vez que estar em desonra significa dizer não às crenças, opiniões e convenções. Quem pratica efetivamente o déshonneur está à mercê constantemente da reprovação das pessoas ao redor. Ele, portanto, é humilhado: "você come como um cão" ... - mas nada terá a ver com a humildade cristã. Ao contrário até, no primeiro caso a humilhação faz parte de um ato afirmativo de si, da própria soberania, de um domínio de si. No segundo caso a infâmia, a desonra, a humilhação são, inversamente, caminhos de renúncia a si (FOUCAULT, 2009, p. 242).

É verdade que a filosofia antiga buscava, nas palavras dos seus pensadores, uma vida correta. Mas isso implicava em se 
ficar atento a todas as convenções, regras, leis e costumes da cidade. Para além da interpretação nietzscheana, segundo a qual Sócrates menos quis respeitar as leis da cidade, aceitando a condenação de beber a cicuta, do que apenas tivera procurado a morte, solução para uma vida depreciada (NIETZSHCE, 2000), Foucault retém essa "ambigüidade" grega: a de seguir a natureza, por um lado, e seguir igualmente as regras sociais. Ambigüidade porque, no segundo caso, entende-se serem eles, os modelos relativos às coisas humanas, passageiras: as escolas filosóficas mudam, as leis e os costumes mudam...

Ora, o cínico busca sair desse equívoco. Somente a natureza é cânon a ser seguido. Por extensão, há aí uma valorização da animalidade. Mas não é o homem que, como tal, destacase desta para constituir-se como homem? O escândalo cínico defende - e experimenta - o contrário: as pessoas são menos do que os animais se não assumirem em si mesmo essa animalidade característica do seu ser. "O bios philosophikos como vida correta é a animalidade do ser humano restabelecida como um desafio, praticado como um exercício, e lançado aos outros como um escândalo" (FOUCAULT, 2009, p. 245).

Pode-se agora voltar à primeira hora da aula foucaultiana. Michel Foucault encontra razões, a partir da análise do pensamento cínico, para traçar uma linha divisória na história da filosofia, ainda que "muito esquematicamente", como alerta. Precisamente, aquela linha que optou por divisar "um outro mundo" e que se encontra desde Sócrates, mas retomado de maneira mais acabada pela filosofia platônica, contraposta à "vida outra" (vie autre), iniciada também com o próprio Sócrates, mas elevada ao máximo com o pensamento cínico. Em resumo, "O outro mundo e a vida outra foram, parece-me 
no fundo, os dois grandes temas, as duas grandes formas, os dois grandes limites entre os quais a filosofia ocidental não cessou de se desenvolver" (FOUCAULT, 2009, p. 226).

O outro mundo platônico é aquele que nasce da contraposição entre o mundo das sombras, carregado de tudo aquilo que é aparente e mutável, e o mundo das formas ou das ideias, aquele "segundo a qual existem entidades eternas, unas e imutáveis", onde a beleza passageira, captada pelos sentidos e correspondente aos seres materiais, são substituídas por uma beleza em si, conceitual, o mesmo valendo para temas como virtude, justiça etc. (RIBEIRO; SARDI; in: PECORARO, Org., 2008, p. 42). Desde a segunda fase da filosofia platônica essa distinção aparece com nitidez, como se vê seja nas partes finais de O Banquete (1989), seja no capítulo VII de A República (2000). Mas a outra vida é, com efeito, aquela em que a alma, perfazendo a prática do cuidado de si, descobre a tarefa da contemplação da transcendência e, nesse sentido, o texto referência para o tema aqui abordado é o Alcebíades, falado anteriormente.

A "vida outra" traz em si questões diversas, que dizem respeito à vida mesma na sua imanência. Nunca perdendo de vista a questão da verdade de uma vida a ser vivida, trata-se de operar uma "ruptura total e sob todos os pontos com as formas tradicionais de existência" (FOUCAULT, 2009, p. 226). Assim, essa linha de pensamento inaugura, ou então dá "fundamento filosófico" ao tema ou questão da "arte de viver". Com uma ressalva, feita por Foucault: essa linha divisória não foi tão estanque assim, houve passagens de um lado para o outro. Porém, no caso de Platão, do cristianismo católico ou mesmo da crítica de Lutero a "vida outra" só entra em causa 
para operar uma conexão com uma ascese ao outro mundo (FOUCAULT, 2009, p. 228).

A partir de tudo o que se disse acima as posições de Gros e de Ortega, apenas anunciadas há pouco como próximas entre si, podem aparecer. Para o primeiro, "A ética cínica da parrhesía [...] pondo a vida à prova" e, a saber, através de um ato de coragem, de ruptura, recusa e denúncia, essa ética que "persegue a verdade e denuncia a mentira" revestiu-se em Foucault não de uma "moral de filósofo", mas de uma "ética do intelectual engajado" (GROS, Org., 2004, p. 166). Quanto à posição de Ortega, os estudos foucaultianos acerca da parrhesía terminaram sendo a "atualização da estilística da existência como foco da resistência às modernas práticas subjetivantes" (ORTEGA, 1999, p. 104). Acrescente-se aqui somente (pressupondo que essa ideia estava presente em Gros e em Ortega) que o estudo foucaultiano acerca da filosofia cínica pode ser "atualizado" se compreende que ela foi não um espelho a ser seguido de maneira literal, senão o limite, "a forma ao mesmo tempo mais rudimentar e a mais radical na qual se colocou a questão dessa forma particular de vida [...] que é a vida filosófica" (2009, p. 219).

Nesse sentido, muitas falas de Foucault, presas a "situações concretas" vivenciadas por ele, foram a ocasião para se encontrar efetivamente uma ancoragem dos seus conceitos e noções. Busca-se falar disso a seguir, embora algumas outras questões de princípio devam ainda ser abordadas, e embora, ao falar dessas "situações concretas" vivenciadas pelas pessoas, ele nunca deixe de relacionar isso a um ponto de vista histórico-filosófico. 
Pensando no tema da ética ele parte do princípio da não crença de que houvesse até "hoje" (ou seja, até a sua morte, em 1984) algum tipo de suporte fixo e universal. Assim, escreve ele, a maioria de nós "não acredita que uma moral possa ser fundada sobre a religião e que nós não queremos um sistema legal que intervenha em nossa vida moral, pessoal e íntima" (DE, IV, 1994, p. 385). Daí os problemas dos movimentos de "liberação" [libération $]^{65}$ em sua época, justamente por "não encontrar princípios sobre o qual fundar a elaboração de uma nova moral" (DE, IV, 1994, p. 386); pior, às vezes querendo atingir algum fundamento, tomando por base os conhecimentos científicos disponíveis sobre o eu, o desejo, o inconsciente etc.

No entanto, não se ter ainda conseguido algum suporte ético-moral não significa partir para algo da ordem de um quietismo ou apatia. Como já foi mencionado anteriormente, se "tudo é perigoso" cabe justamente continuar o trabalho de investigação, ainda que o caminho para isso seja, primeiramente, denunciar as "familiaridades" dentro do espaço social (FOUCAULT, "À propôs de la généalogie de l'étique: um aperçu du travail em cours", DE, IV, 1994, p. 386). É por isso que Foucault atribui ao seu trabalho ser marcado por uma "hiper-militância pessimista", expressão que sintetiza sua tarefa de constituir uma genealogia dos problemas, distinta de uma história das soluções. Bem entendido, não é que tudo seja mau; é que, sendo "perigoso", a todo o instante está-se

65 Libération é um termo francês que tanto pode ser traduzido por "libertação", quanto por "liberação" (nesse último caso diz-se quando alguém é liberado, por exemplo, da obrigação de pagar uma dívida). Os tradutores utilizam uma ou outra versão, a depender do caso. Optou-se aqui, geralmente, por "liberação", palavra com menor cunho metafísico. 
às voltas no cotidiano com disfarces a identificar e com atitudes por tomar. Paradoxalmente, mas só à primeira vista, Foucault diz também partilhar de um "otimista absoluto", já que defende que tudo é contingente e que tudo pode mudar (FOUCAULT, "Entretien avec Michel Foucault", DE, IV, 1994, p. 93). Em síntese, há perigos por todos os lados, assim como sempre há contra-investidas possíveis.

O que não se deve fazer é concordar com modos de sujeição que "convidam" ou "incitam" as pessoas a adotarem escolhas vindas de fora, modos que tornam o sujeito alguém objetivado, seja por ele mesmo, seja pelos outros. Como escreveu Foucault, e essa é outra lição grega, o modo de sujeição da antiguidade era uma "escolha ético-política", não estando à mercê de alguma lei divina ou de uma prática de obediência a um código de regras, como ocorreu no cristianismo (FOUCAULT, “À propôs de la généalogie de l'étique: um aperçu du travail em cours", DE, IV, 1994, p. 398 e FOUCAULT, “Une esthétique de l'existence”, DE, IV, 1994, p. 732). Cabia ao homem grego elaborar uma "arte de viver", da qual houve posteriormente breves episódios: um pouco no Renascimento, sob uma forma "ligeiramente acadêmica", e no "dandismo" do século XIX (FOUCAULT, "À propôs de la généalogie de l'étique: um aperçu du travail em cours", DE, IV, 1994, p. 402).

Hodiernamente falando a recusa por buscar princípios éticos ou conselhos práticos já firmados é um dos poucos conselhos dados por Foucault: "As pessoas devem elaborar sua própria ética" (FOUCAULT, "Une interview de Michel Foucault par Stephen Riggins", DE, IV, 1994, p. 537), ainda mais porque uma moral como obediência a um código de 
regras "está desaparecendo, já desapareceu" (FOUCAULT, “Une esthétique de l'existence", DE, IV, 1994, p. 732). Mas com isso não se afirma ao mesmo tempo que uma ética em Foucault fica impossibilitada, ou que se tornara vazia de conteúdo, sob a indeterminação conceitual presente naquela "arte de viver"? Para Judith Revel, em todo caso, "A estética da existência, na medida em que ela é uma prática ética de produção de subjetividade, é, ao mesmo tempo, assujeitada e resistente: é, portanto, um gesto eminentemente político" (REVEL, 2005, p. 44).

A elaboração autônoma de uma ética não deve ser feita a esmo, mas a partir de uma análise histórica e filosófica. Esse é o sentido da "ontologia histórica de nós mesmos" - e é possível adiantar, da importância do personagem conceitual "crítico", passagem anterior de uma atitude corajosa (de um "cinismo" mitigado) a ser empreendida. Assim, o que se fez das pessoas, o que se disse para elas e as mandaram agir? Não importa, caso não se prenda nisso. Cabe levar a "crítica" adiante, operando uma "fratura virtual" (aí Foucault tenta não apenas copiar Kant, indo para além da pergunta "o que somos?"); na verdade, convidando mesmo a tentar que cada um seja diferente, abrindo "um espaço de liberdade, entendido como espaço de liberdade concreta, isto é, de transformação possível" (FOUCAULT, "Structuralisme et poststructuralisme", DE, IV, 1994, p. 449).

Ou seja, que a crítica seja tanto permanente como experimental, ainda que sempre "limitada", "determinada" e "incompleta" (FOUCAULT, "Qu'est-ce que les Lumières?", DE, IV, 1994, p. 575); porém, só possível porque há como pressuposto dessa ontologia a possibilidade do "trabalho de nós sobre 
nós mesmos como seres livres" (FOUCAULT, “Qu'est-ce que les Lumières?", DE, IV, 1994, p. 575, grifo nosso). Ou então: um labor crítico que sempre necessita de um "trabalho sobre nossos limites, isto é, um labor paciente que dá forma à impaciência da liberdade" (FOUCAULT, "Qu'est-ce que les Lumières?", DE, IV, 1994, p. 578).

Mas se o sentido da palavra "experiência" em Foucault envolve os vastos campos de conhecimentos, o conjunto das regras sociais e a relação do indivíduo consigo mesmo (FOUCAULT, “Qu'est-ce que les Lumières?”, DE, IV, 1994, p. 579) é preciso também reconhecer que ele aponta o "pensamento" como o lugar de instauração dessa realidade, o mecanismo segundo o qual o jogo do verdadeiro e do falso se engendra. De um lado é preciso observar compreensivamente os sistemas de racionalidades que subsidiam todas as coisas ou relações. Mas também ver que a região do pensamento não tem de antemão nenhuma salvaguarda, ninguém que o detenha de uma vez por todas, como alguma posse inalienável. “O pensamento é a liberdade com relação àquilo que fazemos, o movimento pelo qual nele nos desprendemos, constituímo-lo como objeto e o refletimos como problema" (FOUCAULT, "Polémique, politique et problématisations", DE, IV, 1994, p. 597).

O próprio Foucault viu isso na repercussão das suas obras. Ele, que foi criticado por grupos de direita, esquerda e de centro, já que não propunha nenhum "projeto político definido" - ao mesmo tempo viu também as suas idéias se difundirem por frentes as mais diversas. A atitude ética de Foucault, aparentemente neutra ou vazia, e próxima do individualismo - ele escreveu livros não para movimentos de libération, mas "em 
função de uma situação atual" que o interessava (FOUCAULT, "Le souci de la vérité", DE, IV, 1994, p. 674) - terminava sendo uma atitude política. E não conduzia as pessoas ao niilismo, já que, analisando as práticas, sua lógica e suas estratégias, sinalizou ao mesmo tempo para "a maneira pela qual os indivíduos, livremente, em suas lutas, em seus afrontamentos, em seus projetos, constituem-se como sujeitos de suas práticas ou recusam ao contrário as práticas que se lhes propõem". E termina esse trecho: "Eu creio solidamente na liberdade humana" (FOUCAULT, "Interview de Michel Foucault", DE, IV, 1994, p. 693, grifo nosso). Nesse sentido, em resposta a um entrevistador que apontava em Foucault alguém que ligava sempre uma análise a um tipo de ação, conclui que a ética é uma prática e o "ethos, uma maneira de ser" (FOUCAULT, "Politique et éthique: une interview", DE, IV, 1994, p. 587). Kraemer reforça isso, ao dizer: "A noção de êthos evoca a reflexão e ação contínua do homem sobre si mesmo, na convivência com seu grupo, sociedade" (2011, p. 294).

Essa maneira de ser foi estudada por Foucault no momento em que se valeu das "tecnologias de si", como já visto. Em "Les techniques de soi" (DE, IV, 1994, p. 810), complementando, Foucault distinguiu três tipos de técnicas de si: a que se verificou com Sêneca, que tratou da correspondência entre os pensamentos e as regras; a cristã, fazendo nascer uma "hermenêutica de si", na exata medida em que essa tecnologia buscou estabelecer a relação entre os pensamentos humanos escondidos e a impureza da alma; por fim, a tecnologia cartesiana, que investigou a correspondência entre pensamento e realidade. 
Refletir sobre os atos cotidianos, utilizar-se uma tecnologia de si ainda está em questão, contanto que não se cometa o erro de Sêneca e de Epicteto, sobretudo. Ou seja, ao mesmo tempo em que ele propuseram um estilo de existência, fizeram-no como um conselho endereçado a todos (FOUCAULT, "Politique et éthique: une interview", DE, IV, 1994, p. 698); e contanto também que não se siga os passos da hermenêutica cristã, muito mais bem-sucedida em generalizar o normativo e em delegar a resposta da pergunta "quem sou eu?" a um "diretor" de consciência. "O problema da moral como estética da existência foi recoberto pelo problema da purificação” (FOUCAULT, “À propôs de la généalogie de l'étique: um aperçu du travail em cours", DE, IV, 1994, p. 406) e, aos poucos, uma interrogação sobre a moral foi sendo substituída por uma interrogação sobre a verdade e o poder político (FOUCAULT, "Le retour de la morale”, DE, IV, 1994, p. 699).

A coerência de Foucault se mostra aqui mais uma vez: caso se queira de fato operar algum tipo de retorno aos gregos será no sentido de uma retomada da moral, pois "a verdade" mesma não existe, e o poder político não tem nada de necessariamente promissor ou evolutivo. "Recomeçar", pelo pensamento, aquela experiência grega sem, contudo, copiá-la, eis a questão (FOUCAULT, "Le retour de la morale”, DE, IV, 1994, p. 702), levada a bom termo (pelo menos foi o seu último projeto) buscando resgatar a inspiração cínica.

Mas a vida como obra de arte não deve ser tomada em sentido literal ou corrente. Quer dizer, caso se pense, como aproximação, nas artes conhecidas (pintura, escultura etc.), imaginando que elas só têm valor se, ao contrário de quem as criou, puder escapar à morte, imortalizar-se. Bem diferente 
disso a obra da vida, por assim dizer, é "passageira", como já o sabiam os antigos em sua tekhnê tou biou (FOUCAULT, “À propôs de la généalogie de l'étique: um aperçu du travail em cours", DE, IV, 1994, p. 615). Nesse sentido, nova crítica a Sartre. A posição deste autor concedia privilégios inegáveis ao conceito de autenticidade. E, ligando Baudelaire ou Flaubert a tal noção Sartre não viu que o interessante mesmo era fazer o movimento contrário; a saber, "ligar esse tipo de relação a si que se pode ter a uma atividade criadora" (FOUCAULT, "À propôs de la généalogie de l'étique: um aperçu du travail em cours", DE, IV, 1994, p. 393), pensar o homem autêntico não como aquele repetidor de um estilo - de obra ou de vida - mas em um homem que não pára de se reformular, de se inventar diante de uma série de experiências e modos de ser múltiplos. Foucault inverte, pois, a interpretação sartreana, sobretudo se se pensa em Baudelaire, já anteriormente falado.

Foucault não quis profetizar ou tomar certos partidos (por exemplo, como os que questionam se os países do Leste são ou não os melhores a seguir); não quis dizer às pessoas o que fazer. Como almejar ser um "moralista" se não se quer profetizar? Nem uma coisa, nem outra; ou seja, nem buscar a imagem do profeta nem a imagem do guardião da moral: a ética aberta de Foucault começa por aí (FOUCAULT, "Entretien avec Michel Foucault", DE, IV, 1994, p. 92), e mesmo em uma fase tardia da sua vida (em 1982, dois anos antes da sua morte), diz Foucault assustar-se quando o humanismo se esforça para apresentar "uma certa forma de nossa ética como um modelo universal valendo para não importa qual tipo de liberdade" (FOUCAULT, "Verité, pouvoir et soi", DE, IV, 1994, p. 782), ao invés de se voltar para formas criativas de vida, para um futuro que "comporta mais segredos, 
liberdades possíveis e invenções que não nos deixa imaginar [nesse futuro] o humanismo" (FOUCAULT, "Verité, pouvoir et soi", DE, IV, 1994, p. 782).

Retorne-se àquela temática de não prescrever soluções como sendo mesmo uma "escolha política". Coube a Foucault pôr problemas com o máximo de rigor, complexidade e dificuldade possíveis a fim de que uma "solução não nasça de um só golpe" (FOUCAULT, "Entretien avec Michel Foucault", DE, IV, 1994, p. 87). E, com efeito, Foucault diz interessar-se mais pela moral do que pela política, "ou, em todo caso, a política como uma ética" (FOUCAULT, "Politique et éthique: une interview", DE, IV, 1994, p. 586); lembrando de que o problema político mais geral é o da verdade, ou seja, o da repartição entre o verdadeiro e o falso, para então ser possível um governo de si e dos outros (FOUCAULT, "Table ronde du 20 mai, in Perrot (M.), Ed., L'impossible prison", DE, IV, 1994, p. 34). Ou seja, só a partir de uma investigação dessa "relação" de cada um para com essa "verdade", as regras que chancelam o verdadeiro e os efeitos de poder decorrentes daí (FOUCAULT, "La fonction politique de l'intellectuel", DE, IV, 1994, p. 113) é que haverá a ocasião de pôr o problema do governo de si e dos outros. E o interessante disso tudo é que na sociedade atual, pensa Foucault, há sempre uma possibilidade (nesses jogos de verdade) de descobrir algo de diferente e de mudar as regras que aí imperam, seja em parte, seja em sua totalidade (FOUCAULT, "L'éthique du sousi de soi comme pratique de la liberté", DE, IV, 1994, p. 725). Em outras palavras, "Quem diz a verdade? Sujeitos livres que são livres, que organizam um certo consenso e que se encontram inseridos em uma certa rede de práticas de poder e de instituições 
coercitivas" (FOUCAULT, “L'éthique du sousi de soi comme pratique de la liberté", DE, IV, 1994, p. 726).

De um lado há de se mostrar a "brutalidade" de todas as coisas que parecem pacíficas, pois familiares; de outro, e aí Foucault retrabalha a frase sartreana segundo a qual "estamos condenados à liberdade": está-se interligado, na realidade, por todos os lados com aquela chancela do verdadeiro falado acima, fazendo de cada um ser, ao invés, "condenado a confessar a verdade" (FOUCAULT, "Cours du 14 janvier 1976", DE, III, 1994, p. 176). O poder, assenhoreando-se de tal artifício, questiona as pessoas, realiza enquetes, registra, institucionaliza a região ou lugar da verdade, promove castigos e recompensas, faz a lei. Vive-se em uma época em que menos se preocupa em produzir riquezas, do que verdades; em que menos se deve ter atenção para com os gansters do que para com as redes de saber disseminadas pelo social (FOUCAULT, "Sexualité et politique", DE, III, 1994, p. 531). Se o poder pudesse ser localizado, tanto melhor; mas o poder "passa" (FOUCAULT, “Sexualité et politique”, DE, III, 1994, p. 567), e essa sua "velocidade", numa expressão próxima de Deleuze, é que complica.

Mas a inserção do homem nesse meio tão complexo, do qual geralmente ele é cooptado em seu modo de ser e agir, ao revelar igualmente a possibilidade de ser e agir diferentemente possibilita começar a entender duas tão importantes expressões de Foucault: "O que é a ética senão a prática da liberdade, a prática refletida da liberdade?"; "A liberdade é a condição ontológica da ética. Mas a ética é a forma refletida que toma a liberdade" (FOUCAULT, "L'éthique du sousi de soi comme pratique de la liberté", DE, IV, 1994, p. 711 e 712, 
respectivamente). Age-se na exata medida em que se é livre; a liberdade, já de antemão instalada no espaço em que cada um se conduz de uma ou de outra maneira, sinaliza para essa região do ethos, lembrando que Foucault identifica a região da ética como a forma escolhida para adotar um ou outro princípio normativo, ou mesmo inventar outro qualquer. A prática ética será tanto melhor caso o comportamento ou a escolha adotada ocorra no bojo de uma liberdade saída da sua imediatidade irrefletida e posta a pensar. $\mathrm{O}$ homem, em sua liberdade, pode se permitir ficar subserviente aos códigos ou, como que inspirado pelos gregos-romanos, aproximar-se de algo como uma moral do estilo. No primeiro caso poderse-ia fazer, como no exemplo de Foucault, uma história dessa relação a si, mostrando todas as suas mazelas; no segundo caso aproximar-se de tentativas de se chegar a alguma espécie de liberação.

Para concluir essa parte, que se refere a certos princípios abertos adotados por Michel Foucault, merece destaque ainda certas ideias e autores em relação aos quais Foucault demonstrou profunda simpatia. O comentário que ele fez do livro de Deleuze e Guattari, O Anti-Édipo (1976), foi um dos tantos momentos nele carregados de importância. Foucault primeiramente caracteriza o referido livro como livro de ética, pois no geral foi baseado na seguinte investigação: “" como fazer para não nos tornarmos fascistas, mesmo quando (sobretudo quando) acreditamos ser um militante revolucionário?'” (FOUCAULT, “Préface”, DE, III, 1994, p. 135). Posteriormente Foucault acha também servir tal livro como uma espécie de "manual" ou "guia da vida cotidiana", como instrumento de uma renovada ou moderna "arte de viver". 
Foucault sinaliza para vários princípios importantes: devese liberar "a ação política de toda forma de paranóia unitária e totalizante", intensificar "a ação, os pensamentos e os desejos por proliferação, justaposição e disjunção, e não por subdivisão e hierarquização piramidal", liberar-se "das velhas categorias do Negativo (a lei, o limite, a castração, a falta, a lacuna) que o pensamento ocidental há tanto tempo sacralizou como forma de poder e modo de acesso à realidade" preferindo, ao invés, "o que é positivo e múltiplo, a diferença à uniformidade, os fluxos às unidades, os agenciamentos móveis aos sistemas", considerando que "o que é produtivo não é sedentário, mas nômade"; não imaginar que "é necessário ser triste para ser militante, mesmo se a coisa que se combate é abominável. É o vínculo do desejo à realidade (e não a sua fuga nas formas de representação) que possui uma força revolucionária"; não utilizar "o pensamento para dar a uma prática política um valor de verdade; nem a ação política para desacreditar um pensamento, como se fosse apenas uma pura especulação"; nada de exigir da "política que ela restabeleça os 'direitos' do indivíduo, tais como a filosofia os definiu", uma vez que o "indivíduo é o produto do poder. O que é preciso é 'desindividualizar' pela multiplicação e deslocamento os diversos agenciamentos. O grupo não deve ser o laço orgânico que une indivíduos hierarquizados, mas um constante gerador de 'desindividualização'"; por fim, não se deve ser apaixonado pelo poder (FOUCAULT, "Préface", DE, III, 1994, p. 135-136). ${ }^{66}$

66 Deleuze e Guattari, ao contrário, em seu próprio discurso tentaram "neutralizar [seus] efeitos de poder", tornando sua tradução difícil e levando tal discurso a uma instância de humor que, não obstante, denunciava o fascismo político e o fascismo da "nossa vida cotidiana" (FOUCAULT, “Préface”, DE, III, 1994, p. 135-136). 
Uma vez selecionado uma série de princípios, sugestões ou ideias defendidas por Michel Foucault é preciso voltar agora o olhar para aquela questão da atualização das suas posições, lembrando da ressalva feita acima, a saber, que mesmo diante de situações específicas vivenciadas pelas pessoas suas observações sempre são eivadas de posicionamentos histórico-filosóficos. Assim, como levar tal inspiração para os dias de hoje, sem obviamente querer construir sistema, dar conta de tudo? O que interessava a Michel Foucault? Em "Interview de Michel Foucault" (FOUCAULT, DE, IV, 1994, p. 667) ele, dizendo-se não partidário do propósito de se fazer uma luta universal, "um combate universal contra os problemas da humanidade", preferiu tomar partido ou lutar quando algo fosse importante para ele em sua subjetividade. Ele reclama para si essa liberdade, reclama igualmente uma "coerência" em sua vida.

A partir disso é que certos temas podem ser destacados como objetos foucaultianos de análise, em especial, sobretudo na última fase do seu pensamento, o problema do homossexualismo e o do sado-mazoquismo. Começando com o primeiro ponto não há como descartar a importância de aspectos vividos por Foucault. Em 1953 ele abandona o Partido Comunista (PC), sentindo-se pouco à vontade, segundo Eribon, "num partido que rejeitava e condenava a homossexualidade como um vício da burguesia e como um sinal de decadência" (ERIBON, 1990, p. 79). Poderia ter sido também por isso que sai da França rumo a Suécia em 1955: ele criticava a vida sócio-cultural do seu país, embora vá achar no novo exílio sueco repressões similares ao homossexualismo (ERIBON, 1990, p. 100). 
Do ponto de vista histórico-filosófico para Foucault a homossexualidade deve ser uma questão tratada devidamente a partir da sua diacronia. Ou seja, percebendo que houve, relativamente a ela, uma mudança de configuração no tempo, observada segundo três "idades de ouro": primeiro, na Grécia clássica e helenística, onde no início havia a relação atividade-passividade como o importante a ser observado (quem domina?), para posteriormente a pederastia começar a ser posta sob reservas no mundo helenístico. ${ }^{67}$ Há nesse último caso os exemplos de Plutarco e do Pseudo-Luciano, que chegaram ora a legitimar, ora a desqualificar tal prática, embora não se verificasse aí um "limite severo" entre relações homo e hétero. O grave disso, em todo caso? - "seu declínio crescente como tema vivo de uma estilística da existência" (FOUCAULT, 2002c, p. 255 e 264).

A segunda idade de ouro da referida problemática encontra-se no mundo cristão-medieval, onde o que vai importar é o casamento heterossexual, já que o objetivo do sexo é a procriação. Algo de grave aqui será, sobretudo, a "diminuição da importância das relações pessoais de philia" ou amizade, "assim como a valorização do casamento e do vínculo efetivo entre esposos" (2003f, p. 253). Com isso uma discussão teórica e moral sobre o assunto vão eclipsar, diminuir em intensidade, seriedade e "algo de vivo" (2003f, p. 251).

67 Foucault vai falar de uma "quadritemática" da Antiguidade: austeridade sexual em termos do corpo; instituição do casamento; relações entre homens e existência da sabedoria, tudo isso colocado a partir de uma moral de homens livres, pensada, escrita e ensinada por eles e para eles (FOUCAULT, 2003d, p. 33). 
Quem sou eu? A partir do Cristianismo a resposta a essa pergunta está condicionada à minha escolha sexual: tal foi o que se colocou muito cedo no Ocidente (FOUCAULT, "Non au sexe roi", DE, III, 1994, p. 257). Depois, outros setores da sociedade - administrativos, políticos, policiais - cercamse dessa prerrogativa e chegam à personalidade do indivíduo (FOUCAULT, "Interview de Michel Foucault”, DE, IV, 1994, p. 660). É todo um conjunto bem formado que Foucault chama de "dispositivo de sexualidade", ou seja, um "conjunto de práticas, instituições e conhecimentos" que fizeram da região da sexualidade "um domínio coerente" (FOUCAULT, “Interview de Michel Foucault", DE, IV, 1994, p. 662).

Foucault faz notar que a homossexualidade tornou-se problema a partir do século XVIII, com a polícia e o sistema jurídico. A razão disso estava ligada justamente ao desaparecimento daquela amizade, que antes simplesmente deixava a existência de relações sexuais entre os parceiros como algo sem importância, pois aceita pela cultura. Assim, "O desaparecimento da amizade como relação social e o fato de que a homossexualidade tenha sido declarada problema social, político e médico fazem parte do mesmo processo" (FOUCAULT, "Michel Foucault, une interview: sexe, pouvoir et la politique de l'identité", DE, IV, 1994, p. 745).

Nos séculos XVI e XVII isso desaparece ("pelo menos a sociedade masculina"), começando a se "tornar outra coisa". A amizade agora é "perigosa". O exército, a burocracia, a administração e a universidade não poderão "funcionar com amizades muito intensas" e este será um esforço para "diminuir ou minimizar as relações afetivas". O estudo sobre a história da sexualidade bem que poderia dar lugar a um estudo sobre 
a história da amizade, diz ele (FOUCAULT, "Michel Foucault, une interview: sexe, pouvoir et la politique de l'identité", DE, IV, 1994, p. 744). É todo o tema helenístico de uma "estilística da existência a dois", de uma "arte de estar junto", de compartilhar acontecimentos dentro e fora de casa, encontrado no tratado de Antípatros e depois em Musonius - um estilo de relação, claro, sem ter por base alguma lei fixa a ser seguida (FOUCAULT, 2002c, p. 229-232).

Dando o esboço de uma certa "história da amizade" ainda por fazer Foucault diz que, enquanto ela permanecia viva, ninguém percebia se havia entre homens relações sexuais ou, pelo menos, se percebessem isso não tinha importância. $\mathrm{O}$ mesmo movimento que redundou no desaparecimento da "amizade como relação social" foi o mesmo que tornou a homossexualidade um "problema social, político e médico" (FOUCAULT, "Michel Foucault, une interview: sexe, pouvoir et la politique de l'identité", DE, IV, 1994, p. 745). Mas, pergunta-se a ele, "Quais tipos de instituições devemos começar a instaurar, a fim não somente de nos defender, mas também de criar novas formas sociais que constituiriam uma verdadeira solução de mudança?" ("Michel Foucault, une interview: sexe, pouvoir et la politique de l'identité", DE, IV, 1994, p. 745). Michel Foucault não tem uma resposta cabal; diz apenas que isso talvez não devesse começar pela instituição familiar ou por outras que "fazem par com a família"; e acrescenta: "Nossa tarefa, creio, é tentar elaborar uma solução" (FOUCAULT, "Michel Foucault, une interview: sexe, pouvoir et la politique de l'identité", DE, IV, 1994, p. 745).

Se a questão da amizade é algo que o interessa hoje em dia (e ele está falando em 1984) é porque ela afeta e recusa 
as relações institucionais: embora ainda seja uma relação social, as pessoas envolvidas possuem certa liberdade entre si, uma liberdade de escolha que passa, em geral, por poder "viver relações afetivas interessantes" ("Michel Foucault, une interview: sexe, pouvoir et la politique de l'identité", DE, IV, 1994, p. 744). Assim, pensa Foucault, enquanto o exército, a burocracia, a administração, as universidades e escolas se esforçam para "diminuir ou minimizar as relações afetivas, o contrário disso se dá numa relação entre amigos (FOUCAULT, "Michel Foucault, une interview: sexe, pouvoir et la politique de l'identité", DE, IV, 1994, p. 744).

O "amigo" em Foucault, como chama a atenção o estudo de Francisco Ortega (1999), não é um conceito bem demarcado. Ele aparece apenas uma vez, quando diz ser a amizade "'a soma de todas as coisas mediante as quais se pode obter um prazer mútuo'" (FOUCAULT, apud ORTEGA, 1999, p. 162). Mas as referências esparsas de Foucault sobre essa noção mostram assim mesmo que seu conceito não se alinha a certas perspectivas sociológicas e filosóficas tradicionais, que dizem ser a amizade uma "relação voluntária baseada na transparência da comunicação e verdade da informação" (ORTEGA, 1999, p. 168). Em Foucault, a amizade representa uma relação "agonística", quer dizer, "relações livres, que apontam para o desafio e para a incitação recíproca e não para a submissão ao outro" (ORTEGA, 1999, p. 168).

A homossexualidade teve cada vez mais lugar na reflexão médica, que se apropriou do corpo, realidade biopolítica, segundo uma "estratégia biopolítica", (FOUCAULT, "La naissance de la medicine sociale”, DE, III, 1994, p. 211, grifo nosso), porque tal disciplina concentrará em muito os seus interesses 
relativos ao campo da sexualidade (FOUCAULT, "Le pouvoir, une bête magnifique", DE, III, 1994, p. 382), qualificando agora o homossexual (devidamente distinguido por sua opção sexual) como alguém fora dos padrões de normalidade, como um "anormal". Se isso ainda acontece hoje? Embora a sexualidade não seja mais o "grande segredo" da individualidade humana "ela ainda é um sintoma, uma manifestação desse segredo" (FOUCAULT, "Une interview de Michel Foucault par Stephen Riggins", DE, IV, 1994, p. 533).

A psiquiatria teve papel importante em tudo isso. Por volta de 1870 ela começou a se debruçar sobre os homossexuais, dando lugar a inúmeras intervenções e controles, época do internamento deles nos asilos com finalidade de cura. Se, escreve Foucault, antes do século XIX os homossexuais eram percebidos como libertinos e às vezes como delinqüentes, começarão a ser percebidos no parentesco com os loucos, "doentes do instinto sexual" (FOUCAULT, "Non au sexe roi", DE, III, 1994, p. 260 e FOUCAULT, "Une interview de Michel Foucault par Stephen Riggins", DE, IV, 1994, p. 533). Expoentes como Wilde ou Gide surgem, então, fazendo uma contrapartida desse poder psiquiátrico, levando até a literatura algo do mundo homossexual, contra-investida válida e tanto melhor quando é uma estratégia criativa (FOUCAULT, “Non au sexe roi", DE, III, 1994, p. 261).

Porém, seriam as instituições mais tradicionais e protegidas como a família mais "ricas", "interessantes" ou "criativas" do que os grupos marginais (FOUCAULT, "Michel Foucault, une interview: sexe, pouvoir et la politique de l'identité", DE, IV, 1994, p. 745)? Além disso, não seriam as gamias, as relações por demais institucionalizadas, que fixam as relações sexuais 
sob o jugo de um sistema, lei ou contrato sinais de empobrecimento cultural e relacional (FOUCAULT, "Hanzai tosite no chishiki” ('Le savoir comme crime'), DE, III, 1994, p. 83)? Esquivar-se dessas dúvidas em prol de uma ciência qualquer aprofundada foram os perigos dessas regiões de saber, aparentemente tão comprometidas com a objetividade do conhecimento, mas que Foucault quis denunciar nos seus vínculos com o poder e no que acarreta de cerceamento da liberdade, caso fosse levar seus efeitos às últimas conseqüências.

A pergunta acerca do eu ganha, então, em complexidade, ou muda de figura. “Que ser sexual é você?" Isso agora é que estará em jogo. Mas Foucault foi contra fazer tal imbricação e, por conta disso, foi mal compreendido pelos movimentos sexuais. Ainda que disser "'eu sou um homossexual'" possa em algum momento ser válido, na medida em que a sua prática é oposta, barrada, desqualificada, e, como pensou G. Le Gaufey, está fora dos sistemas de alianças reconhecidos, coisa que não acontece com as mulheres, (FOUCAULT, "Le jeu de Michel Foucault", DE, III, 1994, p. 322), apesar disso Foucault não defende a prisão a etiquetas identificadoras. Como afirma, "É preciso recusar satisfazer à obrigação de identificação pelo intermédio e ajuda de uma certa forma de sexualidade" (FOUCAULT, "Interview de Michel Foucault", DE, IV, 1994, p. 662).

Daí ele não ter se enquadrado em nenhum movimento de libèration sexual, mas ocupar-se de casos específicos, como o aborto; ocupar-se com os "modos de vida" que as pessoas adotam, cujo elemento sexual é apenas mais um componente, reenviando todo esse conjunto a uma tecnologia de si (FOUCAULT, “Interview de Michel Foucault”, DE, IV, 1994, p. 
663). Uma citação de Foucault resume exemplarmente o que se escreveu acima. Antes de perguntar 'quem sou eu?', a partir do questionamento sobre a homossexualidade, perguntar:

\begin{abstract}
'Quais relações podem ser, através da homossexualidade, estabelecidas, inventadas, multiplicadas, moduladas?' O problema não é descobrir em si a verdade do seu sexo, mas é antes de usar doravante de sua sexualidade para chegar a multiplicidades de relações (FOUCAULT, "De la amitié comme mode de vie", DE, IV, 1994, p. 163).
\end{abstract}

Enquanto surge nesse jogo, nesse dispositivo o indivíduo "perigoso", e a sexualidade se torna uma região específica de controle, era de se supor que o problema consistiria em mudar a legislação, as leis. Isso estaria incompleto, entretanto. É certo que é preciso, para uma liberação sexual, tanto compreender o envolvimento nesse dispositivo, quanto tentar desgarrar-se dele (FOUCAUL, “Non au sexe roi", DE, III, 1994, p. 260), sem cair numa visão maniqueísta do tipo "meu lado é o melhor ou o bom" (FOUCAUL, “Non au sexe roi", DE, III, 1994, p. 265 entre aspas, expressão nossa), ou se fechar em grupos ou guetos (FOUCAULT, “M. Foucault. Conversation sans complexes avec le philosophe qui analyse les 'structures du pouvoir'", DE, III, 1994, p. 678). Porém, a luta não deve ser realizada apenas do lado da legislação. A lei pode determinar direitos, mas ainda assim certas discriminações podem ser verificadas. A luta pelos direitos dos homossexuais e das outras minorias não é, pois, a "etapa final". Há de se lutar também no nível dos comportamentos, das atitudes das pessoas frente a essas 
minorias: "Um direito, em seus efeitos reais, está muito mais ligado ainda a atitudes, a esquemas de comportamentos do que a formulações legais" (FOUCAULT, "Le triomphe social du praisir sexual: une conversation avec Michel Foucault", DE, IV, 1994, p. 308).

Com isso é possível agora voltar àquela questão anunciada anteriormente. A saber, por que Foucault não gosta da expressão homossexual? Porque o meu "eu" não pode ser identificado pelo seu componente sexual, e aí o tema do poder e da "subjetivação" em Foucault ganham corpo. Poder, pois como alguém pode se associar a uma estratégia de luta promissora, quando permanece preso nessa região localizável, identificável, alvo tão exposto ou aberto para ele? Melhor seria não ser tão visível assim, melhor seria não buscar uma identidade por demais fixa, e é isso o que sempre quis Michel Foucault: pensar estratégias para os diversos problemas, sempre pressupondo que onde há poder há resistência, e que o "dizer não" é apenas a sua expressão mais imediata, em muitos casos insuficientes.

Mas nem sempre acontece "dizer não" de forma costumeira ou seguindo tendências do momento. Daí porque Foucault, filosoficamente falando, não quisera se encaixar dentro de alguma espécie de anarquismo libertário, representado por aquele ativista que "crê nas necessidades fundamentais do homem" (FOUCAULT, "Interview de Michel Foucault", DE, IV, 1994, p. 667). Não há uma natureza humana. Ao contrário disso, é preciso mesmo produzir um homem, "produzir alguma coisa que não existe ainda e da qual nós não podemos saber o que será" (FOUCAULT, "Entretien avec Michel Foucault", DE, IV, 1994, p. 74). 
Quanto ao tema da subjetivação, entendendo por esta "o processo pelo qual se obtem a constituição de um sujeito, mais exatamente de uma subjetividade" (DE, IV, 1994, p. 706), há de se resgatar alguma mediação histórica. Foucault chegou a retomar o movimento de 1964, quando a universidade francesa entrara em profunda crise, "ao mesmo tempo política e cultural", movimento animado pelos estudantes para se "desembaraçar do quadro da vida estritamente universitária". Tal movimento se identificou com o das feministas e dos direitos dos homossexuais. Após os anos 60 subjetividade, identidade e individualidade, pensa Foucault, tornaram-se os problemas emergentes. Ele, porém, achou "perigoso" as pessoas se valerem dos dois primeiros, no sentido de considerá-los como "componentes profundos e naturais", ao invés de ver como fatores políticos e sociais os determinavam. A saída estava em promover uma liberaração de uma subjetividade aí instalada pelos psicanalistas, que aqui ou ali pretendem dizer quem é cada um e o que se deve fazer: "Nós devemos liberar nossa subjetividade, nossa relação a nós mesmos" (FOUCAULT, "Foucault étudie la raison d'État", DE, III, 1994, p. 801).

Em outras palavras, o sujeito não é algo que de repente pode aparecer em sua substância ou natureza, saído de alguma espécie de crisálida, dê-se a isso o nome de alienação ou outro conceito qualquer. O sujeito, como "forma" (FOUCAULT, "L'éthique du souci de soi comme pratique de la liberté", DE, IV, 1994, p. 719), é o resultado de um processo histórico, e um resultado sempre movente, pois ele não para de remanejar o seu ser. É preciso operar um deslocamento nos jogos de verdade, com suas práticas coercitivas, rumo a uma "prática de autoformação do sujeito", ou seja, para um "exercício de si 
sobre si pelo qual se procura elaborar, transformar-se e chegar a um certo modo de ser" (FOUCAULT, "L'éthique du souci de soi comme pratique de la liberté", DE, IV, 1994, p. 709). Uma experimentação que se opõe ao sentido fenomenológico, já que uma experiência segundo tal corrente busca uma significação do vivido. Ao contrário disso, uma experiência como a pensada por Nietzsche, Bataille ou Blanchot teria por tarefa "arrancar o sujeito dele mesmo", até a sua supressão ou a sua dissolução. É uma empresa de "des-subjetivação", como em uma experiência -limite, que não reenvia o sujeito à sua identidade (FOUCAULT, “Entretien avec Michel Foucault", DE, IV, 1994, p. 43).

Mas conquanto que todo esse esforço não seja reenviado para um processo de libertação, como uma etapa definitiva de conquista. Foucault insiste em distinguir esse processo, como tal quimérico, de "práticas de liberdade", este sim possível, real e relevante como problema ético (FOUCAULT, "L'éthique du souci de soi comme pratique de la liberté", DE, IV, 1994, p. 710). Práticas entendidas como uma reversão de "esquemas que ele [o homem] encontra em sua cultura e que lhe são propostos, seguidos, impostos por sua cultura, sua sociedade e seu grupo social" (FOUCAULT, "L'éthique du souci de soi comme pratique de la liberté", DE, IV, 1994, p. 719).

Porém há limites teóricos aqui. O próprio Foucault achava que não tinha avançado muito na questão de saber se o cuidado de si poderia ser "o cerne de um novo pensamento político" (FOUCAULT, "L'éthique du souci de soi comme pratique de la liberté", DE, IV, 1994, p. 722). O sujeito político, de Rousseau e Hobbes até o século XIX, segundo ele, foi pensado como sujeito de direito - ora naturalista, ora do direito positivo. Ao contrário, o pensamento político contemporâneo não 
se vale de uma reflexão sobre o sujeito ético. Se algo ainda é característico das pessoas indiscutivelmente é a preocupação com a verdade, ou com a sua verdade, vitória do conhece-te a ti mesmo sobre o cuidado de si. ${ }^{68}$ Ora, preocupação que deve ser posta em xeque, tanto recusando buscar alguma identidade fixa, como já foi dito, quanto valorizar, bem ao contrário, todos os processos de "diferenciação" que se pode percorrer no próprio ser de cada um. Se buscar algo de identidade dá prazer a alguém, que não haja condenação disso; mas tal busca não pode levar à formulação de uma ética universal (FOUCAULT, “Michel Foucault, une interview: sexe, pouvoir et la politique de l'identité", DE, IV, 1994, p. 739).

E o que se deve formular ou criar, então? Não um gueto onde a identidade homossexual (ou outra qualquer) fosse alardeada pelos quatro cantos. Deve-se pensar nesse caso em uma "ascese homossexual" ou "modo de vida gay", em um primeiro momento, e, por fim, elaborar uma nova forma ou expressão cultural, o que realmente importa. Começando pela primeira ideia, Foucault pensa que a sociedade atual tem medo não tanto do ato sexual mesmo, de sua não conformidade com a lei ou a natureza, mas medo de que se formem alianças, de que "linhas de força imprevistas" surjam; em suma, medo de que o "modo de vida homossexual" se instale (FOUCAULT, "De la amitié comme mode de vie", DE, IV, 1994, p. 164). Foucault distingue ascetismo (como renúncia

68 Foucault mostra como no período helenístico o cuidar de si se via nas cartas escritas pelos filósofos ou sábios, "lembranças daquilo que o indivíduo fez, e não daquilo que ele pensou" (FOUCAULT, "Les techniques de soi", DE, IV, 1994, p. 795). Essa foi uma das diferenças relativas ao período cristão, pois a prática monástica insistirá sobre um exame de consciência bastante distinto. 
ao prazer) de ascese. Esta é um trabalho que se faz sobre si mesmo, no sentido de se transformar internamente. Ora, o problema hoje, reflete ele, talvez fosse "avançar em uma ascese homossexual que nos faria trabalhar sobre nós mesmos e inventar, eu não digo descobrir, uma maneira de ser ainda improvável" (FOUCAULT, "De la amitié comme mode de vie", DE, IV, 1994, p. 165). A tarefa por fazer: se liberar os desejos, que seja para entregá-los a novos prazeres.

O homossexual está preso a "traços psicológicos" que o saber estabelecido the imputou; a ascese ou modo de vida, a uma virtualidade de relações e acontecimentos fruto das "linhas diagonais" que essas minorias podem fazer surgir. Trata-se de inverter ou prolongar as expectativas: "lutar intensamente para ser gay", realizar um devir-gay, significa usar a escolha sexual como "ponte" para novas formas de existência (FOUCAULT, “Entretien avec Michel Foucault", DE, IV, 1994, p. 295).

A segunda questão pendente, a criação de novas formas culturais, vem como decorrência da inventividade da ascese aqui abordada. Foucault escreve sem meias-palavras: "Nós devemos criar uma cultura. Nós devemos realizar criações culturais" (FOUCAULT, "Michel Foucault, une interview: sexe, pouvoir et la politique de l'identité", DE, IV, 1994, p. 737). Mas que se entenda bem isso: a cultura deve ser compreendida em sentido amplo, não importa se vindo de guetos minoritários ou não, contanto que se estabeleça uma novidade relativa a valores, procedimentos, relações etc. Levando isso a toda a sua extensão poder-se-ia vislumbrar inclusive a troca ou transferência desses valores renovados pela malha social, por exemplo, dos homossexuais para os heterossexuais (FOUCAULT, "Le triomphe social du praisir sexual: une 
conversation avec Michel Foucault", DE, IV, 1994, p. 311). Então, a palavra de ordem não é "reintroduzir a homossexualidade" no espaço da normalidade social, mas, diferentemente disso, deixar que ela escape para esse outro meio mais pobre e fechado, ao ponto de fazer até com que pessoas não homo possam "enriquecer sua vida, modificando seu próprio esquema de relações" (FOUCAULT, "Le triomphe social du praisir sexual: une conversation avec Michel Foucault", DE, IV, 1994, p. 311).

Do ponto de vista filosófico há aí, pela ótica de Foucault, uma preferência por Kant ao invés de Descartes. Descartes perguntava: quem sou eu? Kant, por sua vez, recoloca a questão, mas introduzindo uma pequena e fundamental modificação nisso: "'quem somos nós, nesse momento preciso da história?-'” (FOUCAULT, “Le sujet et le pouvoir", DE, IV, 1994, p. 232). Talvez hoje não se possa compreender o presente sem um recuo na história, na direção de traços do cristianismo, de sua colocação de um sujeito contaminado pela concupiscência de origem e cuja estética da existência grega foi "recoberta" pelo tema da purificação (FOUCAULT, "À propôs de la généalogie de l'éthique: un aperçu du travail en cours", DE, IV, 1994, p. 406). Desse quadro pode nascer uma tarefa atual: "O problema ao mesmo tempo político, ético, social e filosófico que se põe a nós hoje não é tentar liberar o indivíduo do Estado e de suas instituições, mas [...] do tipo de individuação que está ligado a ele" (FOUCAULT, "Le sujet et le pouvoir", DE, IV, 1994, p. 232).

Esse desejo de "liberação", como visto, ainda não encontrava suporte pleno na Antiguidade pré-cristã, um modelo a ser seguido absolutamente. Não obstante, achava Foucault 
que algum tipo de "comparação" era possível de se fazer. Os gregos do século IV a.C. conseguiram, por exemplo, relacionar de maneira "forte" o prazer e o desejo: "A moral grega do prazer está ligada à existência de uma sociedade viril, à idéia de dissimetria, à exclusão do outro, à obsessão da penetração, a essa ameaça de ser privado de sua energia", enfim, a uma "atividade": "vós sois o escravo ou o senhor dos vossos desejos?" (FOUCAULT, “À propôs de la généalogie de l'éthique: un aperçu du travail en cours", DE, IV, 1994, p. 614).

Nesse sentido, não se via aí falar em coisas como bissexualidade, por exemplo. Havia apenas um desejo, não dois, ou duas pulsões digladiando entre si. Importava procurar os seres 'belos', qualquer que fosse o sexo destes (FOUCAULT, 2003d, p. 245). O gosto que cada um devia ter não apontava para uma "questão de tipologia, implicando a própria natureza do indivíduo, a verdade de seu desejo ou a legitimidade natural de sua inclinação" (FOUCAULT, 2003d, p. 247). Se havia algo de "desprezo" pelos rapazes mais fáceis ou muito interessados, sem falar pelos efeminados, ainda assim não se experimentavam essas jovens pessoas como o "outro". Não se precisava ver naturezas distintas nas pessoas que pendiam para os moços ou as moças, embora se precisasse, em cada caso, dar uma formatação moral específica (FOUCAULT, 2003d, p. 250). ${ }^{69}$

69 Foucault tentou mostrar como houve por parte de filósofos e médicos dos séculos I e II d.C. toda uma “Desconfiança face aos prazeres, insistência sobre os efeitos de seu abuso para o corpo e para a alma, valorização do casamento e das obrigações conjugais, desafeição com relaçao às significações espirituais atribuídas ao amor pelos rapazes". Ou seja, toda uma "inquietação face aos prazeres sexuais" (FOUCAULT, 2002c, p 55). 
No processo histórico que começa já no período helenístico e que desemboca no cristianismo a questão do prazer, com a estética do seu uso, cederá lugar a uma hermenêutica do desejo, ou "hermenêutica purificadora", como escreve Foucault quase nas últimas frases de L'usage des plaisirs (FOUCAULT, 2003d, p. 327). Sobretudo com o cristianismo, o ato sexual será uma "passividade", fruto do pecado, e os traços imperceptíveis muitas vezes da concupiscência serão aclarados pela penitência e exame de consciência, como já visto anteriormente. A busca pela verdade do prazer encampada pela literatura erótica na seqüência de Sade e Rétif seria a segunda linha decisiva desse percurso em torno da sexualidade, chegando ao último traço, também falado há pouco, referente à tradição mais recente: com os psicanalistas (ao lado da preocupação da medicina em torno da sexualidade), fazendo um contraste do momento acima anterior, atribuiria que " $O$ importante é o desejo e que o prazer não é nada" (FOUCAULT, “À propôs de la généalogie de l'éthique: un aperçu du travail en cours", DE, IV, 1994, p. 390, grifo nosso).

Assim, se ficou famoso o slogan: “'Libere o desejo!'” - os psicanalistas que o anunciavam terminavam seguindo os passos católicos de se chegar a isso pela decifração de si mesmo, expondo (como uma espécie de confissão) os conteúdos do seu inconsciente (FOUCAULT, "Sexualité et politique", DE, III, 1994, p. 527). Antes de ser ciência, escreve Foucault, a psicanálise "é uma técnica de trabalho de si sobre si fundada na confissão. Nesse sentido, é igualmente uma técnica de controle" (FOUCAULT, “Interview de Michel Foucault”, DE, IV, 1994, p. 665). 
Foucault não vai ter dúvidas: tal inclinação foi obra de uma contingência histórica e, nesse sentido, nada obriga ninguém a permanecer nesse quadro de referência. Da pastoral a uma scientia sexualis é a mesma busca pela individualização do sujeito, diferença com o Zen (FOUCAULT, "Michel Foucault et le zen: um séjour dans un temple zen", DE, III, 1994, p. 621); além disso, é o mesmo desejo subjugado pelo discurso da verdade,$^{70}$ cerceando o elemento do prazer nas suas possibilidades infinitas, pois mercê de cânones a seguir (no caso do cristianismo, "des-hedonizar" mesmo a relação sexual - 2002c, p. 244) e de uma natureza humana por não aviltar. É a mesma tendência de desenvolver um saber ou ciência a respeito do sexo - medicalizando-o, como se ele "fosse uma zona de fragilidade patológica particular da existência humana" (FOUCAULT, "Les rapports de pouvoir passent à l'intérieur des corps", DE, III, 1994, p. 235) - quando, ao invés disso, dever-se-ia tentar desenvolver uma arte, com o fim de intensificar o prazer para, quem sabe daí, o desejo poder segui -lo (FOUCAULT, "Sexualité et pouvoir", DE, III, 1994, p. 557 e "Michel Foucault, une interview: sexe, pouvoir et la politique de l'identité", DE, IV, 1994, p. 738). Ou seja, de um lado há uma sexualidade como algo da ordem de uma "fatalidade"; de outro, como algo da ordem de uma "criatividade" em aberto (FOUCAULT, "Michel Foucault, une interview: sexe, pouvoir et la politique de l'identité", DE, IV, 1994, p. 735).

Ora, ainda que choque à primeira vista - um choque bem característico da inspiração cínica, certamente a aproximação

70 Ligar por "espiral" a coerção, o prazer e a verdade, não apenas dizendo "não" (FOUCAULT, "L'Occident et la vérité du sexe", DE, III, 1994, p. 103). 
mais atualizada em Foucault dessa corrente - o sadomasoquismo foi tomado por ele como exemplo de uma tentativa contrária de extrair novas relações, de criar "novas possibilidades de prazer, que não se tinha imaginado antes" (FOUCAULT, "Michel Foucault, une interview: sexe, pouvoir et la politique de l'identité", DE, IV, 1994, p. 737), por mais que, "estupidamente", se diga que se trata de práticas de violência ou coisas do gênero. Eles apenas "inventaram novas possibilidade de prazer, utilizando certas partes bizarras do seu corpo" (FOUCAULT, "Michel Foucault, une interview: sexe, pouvoir et la politique de l'identité", DE, IV, 1994, p. 738).

O sadomasoquismo é uma "erotização do poder": se ora alguém é dominado, ora é este que vai depois reverter a situação e passar a dominar. A estabilidade do jogo, diferentemente do poder social, está sempre cedendo lugar a instabilidades, movimentos, transgressividade de regras. Se o sadomasoquismo é julgado como uma subcultura é porque seu processo inventivo é desconsiderado (FOUCAULT, "Michel Foucault, une interview: sexe, pouvoir et la politique de l'identité", DE, IV, 1994, p.743), é porque não se vê que são tentativas dessa ordem que promovem as modernas "revoluções" atuais, obviamente distintas das revoluções que se tentaram encampar no século XIX (FOUCAULT, "Le savoir comme crime", DE, III, 1994, p. 86).

O movimento sadomasoquismo representa para Foucault, portanto, duas coisas a serem valoradas: primeiro, o seu não atrelamento a normas sociais, que repartem tudo, até mesmo as regiões do prazer e as suas regras; segundo, a iniciativa de criar formas de vida distintas das socialmente recorrentes e admitidas. Entendendo, porém, que esse ato criador não pode 
fundar-se em cânones mesmo no interior de grupos "minoritários": a mulher, os negros, os homossexuais etc. A cada vez que se propõe circunscrever identitariamente nesses grupos começase a cercear o ato criador e a impor limites à liberdade, entendida como forma livre ou não-institucionalizada de relação.

O que não significa que há em Michel Foucault uma apologia ao prazer. Pois, apesar da importância concedida ao elemento do prazer, há também em Foucault uma tentativa de avançar em relação a isso. De um lado precisa-se "dessexualizar o prazer": o movimento sadomasoquista mostrou que o prazer não está apenas referido ao sexo; que o corpo é a ocasião possível de múltiplos prazeres (FOUCAULT, “Michel Foucault, une interview: sexe, pouvoir et la politique de l'identité", DE, IV, 1994, p. 738), sem levar em conta que objetos muito estranhos ainda podem concorrer para a sua intensificação.

De outro lado - e aí Foucault quer avançar no problema assim como ele achou estratégica e teoricamente complicado querer identificar sujeitos a partir de uma categoria sexual (homo, hétero etc.) e conceder demasiada atenção às relações, se baseadas no comportamento sexual, algo muito mais amplo do que isso era ver que há um jogo interpessoal onde entram igualmente a afeição, o amor, o desejo; em suma, toda uma "experiência" mais complexa (FOUCAULT, "Choix sexuel, acte sexuel”, DE, IV, 1994, p. 320). Historicamente, e esse é um exemplo bem apropriado, a cultura cristã "baniu a homossexualidade, forçando-a a concentrar toda a sua energia sobre o ato ele mesmo. Os homossexuais não puderam elaborar um sistema de côrte porque se lhes recusou a expressão cultural necessária a esta elaboração" (FOUCAULT, “Choix sexuel, acte sexuel”, DE, IV, 1994, p. 329). Quando a literatura retomou isso, era natural concentrar-se no aspecto do sexo. 
Nessa foucaultiana necessidade de uma "dessexualização", embora o problema do corpo tenha sido uma obsessão nos seus estudos, nas suas últimas obras há uma indicação para que não seja concedido a isso o fim das metas individuais. É a volta ao tema da amizade, em contraposição às formas institucionais aprisionantes, e Foucault não quer repetir suas práticas. Assim, recusando-se a propor programas futuros a serem seguidos diz que seu papel é mais "mostrar às pessoas que elas são muito mais livres do que elas pensam"; mostrar que há espaços familiares capazes de fazer as pessoas esquecerem de que tudo foi fruto de "mudanças históricas bem precisas". O que quer dizer que, diz ele, "Todas as minhas análises vão contra a ideia de necessidades universais na existência humana" (FOUCAULT, “Verité, pouvoir et soi”, DE, IV, 1994, p. 778-779).

Por que o humanismo não dá conta dessa abertura ora reclamada? O humanismo busca propor esquemas universais; nas palavras de Foucault, "apresenta uma certa forma de nossa ética como um modelo universal valendo para não importa qual tipo de liberdade". O humanismo não consegue vislumbrar "segredos, liberdades possíveis e intervenções" outras que o futuro pode reservar (FOUCAULT, "Vérité, pouvoir et soi", DE, IV, 1994, p. 782).

Segundo Foucault, em "Les techniques de soi" (FOUCAULT, DE, IV, 1994, p. 786), a tradição filosófica Ocidental insistiu muito sobre o "conhece-te a ti mesmo", esquecendo-se do "cuida de ti". Aquela expressão significava: 1- "Não imagine que você seja um Deus", ou "Sabe bem você qual é a natureza de tua demanda quando vens consultar o oráculo?" Diz ainda Foucault: “Nos textos gregos e romanos 
a injunção ao conhecer a si mesmo está sempre associado a esse outro princípio que é o cuida de si, e é essa necessidade de tomar conta de si que torna possível a aplicação da máxima délfica. Essa ideia, implícita em toda a cultura grega e romana, torna-se explícita a partir do Alcebíades I de Platão", um cuidado de si que vai percorrer, pois, tanto a filosofia antiga quanto o ascetismo cristão (FOUCAULT, "Les techniques de soi", DE, IV, 1994, p. 787). Viver hoje em um momento onde o "conhece-te a ti mesmo" tornou-se o princípio fundamental, obscurecendo o "cuida de ti" significa, por um lado, como por paradoxo, que a herança moral cristã recomenda um autoconhecimento como renúncia a si (FOUCAULT, "Les techniques de soi", DE, IV, 1994, p. 788); por outro lado, a moral de hoje, vinda desde o século XVI, repousa sobre um fundamento ligado a uma lei externa. Em suma, "o si era a instancia que poderia rejeitar" (FOUCAULT, "Les techniques de soi”, DE, IV, 1994, p. 789);

O cristianismo se classifica como uma religião da saúde, confessional, que "impõe obrigações muito estritas de verdade, de dogma e de canon"; ou seja, cada um deve buscar saber o que se passa consigo, "reconhecer suas faltas, admitir suas tentações, localizar seus desejos" e revelá-las a Deus, e isso através de técnicas como a penitência e a confissão, além da exomologêsis (FOUCAULT, "Les techniques de soi", DE, IV, 1994, p. 804-805-805). Mas o importante é saber que na penitência não se trata de "revelar a verdade do pecado, mas de mostrar a verdadeira natureza pecaminosa do pecador" (FOUCAULT, "Les techniques de soi", DE, IV, 1994, p. 807). Há a ideia de que habita em nós uma "concupiscência secreta" (FOUCAULT, "Les techniques de soi”, DE, IV, 1994, p. 810); a continuação, pelas ciências humanas, de técnicas 
de verbalização cristãs não reinscreveu o sujeito no objetivo de sua renúncia a si, mas no "instrumento positivo da constituição de um novo sujeito" (FOUCAULT, "Les techniques de soi", DE, IV, 1994, p. 813);

O sujeito foucaultiano, portanto, deve pautar-se em uma liberdade criadora, deve ensejar novas relações, novas formas culturais, sem atrelar tudo isso a um ideal de vida altivo, como nos gregos. O que há de belo na existência de cada um? É em vão buscar uma resposta disso em Michel Foucault, e ele mesmo chegou a dizer que sua vida, do ponto de vista biográfico, não tinha muita importância, ao contrário da vida sartreana, por exemplo. Menos glamour, portanto, e mais criatividade, é a resposta de Michel Foucault a Sartre.

Mas quem pode criar? A criação de novos modos de vida pertence a todos. Há o esteta foucaultiano, cioso de todas as formas sociais de poder que o sujeita, e o pequeno esteta, o homem comum, com uma consciência crítica ainda ingênua, sem ter dado conta de todas as ferramentas conceituais trabalhadas por Foucault, mas cuja sensibilidade e coragem para enfrentar os poderes e normatizações instituídas levaram-no a se tornar um esteta da existência. ${ }^{71}$ Essa ideia transparece na entrevista "Os intelectuais e o poder", onde Foucault e Deleuze encontram momentos para se referir ao aspecto de

71 Daí algumas ressalvas relativamente a uma inclinação intelectualista em alguns momentos de Kraemer: "Ao se conhecerem os modos históricos do jogo poder-verdade é que se pode vislumbrar, na dinâmica mesma do jogo, a possibilidade da liberdade" (KRAEMER, 2011, p. 298); ou então esta parte: "O princípio da autonomia pressupõe o trabalho da Crítica" - embora concordemos com ele se tudo isso for apenas referido a uma situação de autonomia ideal, enlaçando um pensamento crítico vigoroso com uma atitude criadora inédita. 
que as massas não são carentes de saber, uma vez que elas, por estarem alocadas em situações específicas, são as que conhecem efetivamente o problema e o teor do enfrentamento, embora não tenham os meios garantidos para o ato de denúncia, daí a necessidade do intelectual:

Ora, o que os intelectuais descobriram recentemente é que as massas não necessitam deles para saber; elas sabem perfeitamente, claramente, muito melhor do que eles; e elas o dizem muito bem. Mas existe um sistema de poder que barra, proíbe, invalida esse discurso e esse saber (FOUCAULT, 1979, p.71). ${ }^{72}$

É esse mesmo sistema de poder que conduz as pessoas ao patamar de "infames". É claro que tudo isso está um pouco no reino das suposições, pois a morte prematura de Michel Foucault em 1984 deixou mais hiatos do que pontos contínuos. Dessa forma, é válida a reflexão de Paulo Vaz: “[...] a infâmia tem uma articulação diferente entre esquecimento e memória: seu renome só se dá na luta contra o poder. Talvez pensasse Foucault: se é para ser autor, que ao menos seja um infame, usado e lembrado nos instantes em que se resiste" (VAZ, 1992, p. 30).

72 O estudo foucaultiano acerca do sistema carcerário pode ser adequado àquilo que se está falando. Tendo em vista que a instituição prisão é como um iceberg, ou seja, o que está aparente é a parte das justificações: “'[...] precisa-se das prisões porque há criminosos"” (FOUCAULT, "Enquête sur les prisons: brisons les barreaux du silence", DE, I, 2001, p. 1047), mas isso é apenas o lado mais visível, não a radiografia completa da questão, e Faucault chegou a dizer:“É necessário transformar a experiência individual em saber coletivo. Quer dizer, em saber político" (FOUCAULT, "Enquête sur les prisons: brisons les barreaux du silence", DE, I, 2001, p. 1046). 